


\section{Belajar sambil Mengajar: Menghadapi Perubahan Sosial untuk Pengelolaan Sumberdaya Alam}

Agus Mulyana

Hasantoha Adnan

Yayan Indriatmoko

Agus Priyono

Moira Moeliono 


\section{Belajar sambil Mengajar: \\ Menghadapi Perubahan Sosial untuk \\ Pengelolaan Sumberdaya Alam}

Penulis:

Agus Mulyana, Hasantoha Adnan, Yayan Indriatmoko,

Agus Priyono, dan Moira Moeliono

Penyunting:

Agus Priyono

Foto sampul:

Rifky

Foto halaman dalam:

Rifky, Andhika Vega Praputra, dan Arief Luqman Hakim

Desain grafis dan tata letak:

Rifky dan Andhika Vega Praputra

ISBN: 978-979-|4| 2-49-0

(C) 2008 CIFOR

Hak cipta dilindungi oleh Undang-undang

Dicetak oleh Penebar Swadaya, Jakarta

\section{Penerbit:}

Center for International Forestry Research (CIFOR)

Alamat Pos: P.O. Box 0113 BOCBD, Bogor 16000, Indonesia

Alamat Kantor: Jl. CIFOR, Situ Gede, I6II5, Indonesia

Telp: +62 (025I) 622622. Fax: +62 (025I) 622100

E-mail: cifor@cgiar.org

Situs Web: http://www.cifor.cgiar.org 


\section{DAFTAR ISI}

Serambi Belajar Bersama

Tabur Kasih

\section{BAB I}

Shared Learning: Konsep dan Praktik dalam Pengelolaan Hutan Multipihak di Indonesia

Pendahuluan

Tujuan Buku

Belajar Bersama

Shared Learning sebagai Pendekatan Pembelajaran Sosial 8

$\begin{array}{ll}\text { Shared Learning, sebuah Praktik } & 10\end{array}$

$\begin{array}{ll}\text { Prinsip-prinsip Utama Shared Learning } & 13\end{array}$

\section{BAB II}

\section{Tiga Langkah Meracik Shared Learning}

Langkah Pertama: Perencanaan dan Persiapan Shared Learning 16

$\begin{array}{ll}\text { Tema dan Tujuan Pembelajaran } & 17\end{array}$

Penyusunan Kerangka Acuan $\quad 18$

Refleksi Seri Shared Learning sebelumnya 19

Bergerak Bersama: Penyelenggara, Fasilitator, Peserta,

Reviewer dan Narasumber $\quad 19$

Merancang Proses Pembelajaran 25

Menentukan Lokasi Kajian Lapangan 26

Langkah Kedua: Penyelenggaraan dan Fasilitasi Shared Learning 28

Pembukaan dan Orientasi 29

Berbagi Pengalaman $\quad 30$

Kajian Lapangan $\quad 32$

Evaluasi, Refleksi, dan Rencana Tindak Lanjut 34 
Langkah Ketiga: Menata Kegiatan Pasca-Shared Learning 35

Menerbitkan Pembelajaran Bersama 35

Pembentukan Jaringan $\quad 35$

Pengembangan Kemitraan 36

\section{BAB III}

Fasilitasi dan Fasilitator: Menebar Proses, Menuai Perubahan Apa dan Mengapa Fasilitasi 38

Nilai-nilai Dasar Fasilitasi dalam Shared Learning 4I

Fasilitator dalam Shared Learning $\quad 42$

Sikap dan Ketrampilan Fasilitator $\quad 44$

Kiat Mengatasi Rintangan Fasilitasi Belajar Bersama $\quad 49$

Sikap Fasilitator 49

Krisis Kelompok $\quad 50$

Dilema Waktu $\quad 50$

\section{BAB IV}

Metode dan Teknik Belajar: Memetik Pengalaman Bersama

Memandu Proses Belajar 54

Mengenal Diri Sendiri $\quad 55$

Seminar $\quad 55$

Pembekalan $\quad 55$

Berbagi Pengalaman dari Berbagai Lokasi $\quad 56$

Klinik $\quad 56$

Tinjauan Reviewer $\quad 56$

Film Dokumenter $\quad 57$

Jurnal Harian, Rekaman Foto dan Video $\quad 57$

$\begin{array}{ll}\text { Kajian Lapangan } & 57\end{array}$

\section{BAB V}

\section{Penutup: Menimbang Buah Shared Learning}

Dampak Shared Learning $\quad 62$

Pembelajaran bagi Pengelolaan Sumberdaya Alam Indonesia 65

Tantangan dan Saran 68

$\begin{array}{ll}\text { Melanggengkan Pembelajaran Bersama } & 72\end{array}$

$\begin{array}{ll}\text { Bahan Bacaan } & 73\end{array}$ 


\section{Serambi Belajar Bersama}

Buku ini menawarkan satu pendekatan untuk membantu pihak-pihak yang berkepentingan menghadapi ketidakpastian dan ketidaktahuan pengelolaan alam secara berkelanjutan. Kurangnya pemahaman tentang sistem-sistem kehidupan mengharuskan pendekatan pengelolaan yang lentur, kreatif dan adaptif. Untuk itu, siapapun perlu belajar secara terus-menerus: belajar untuk belajar; belajar untuk memantau akibat tindakan yang diambil terhadap sistem yang dikelola; belajar untuk menyesuaikan diri; dan, belajar bekerja sama dengan berbagai pihak lain.

Pendekatan belajar bersama yang dijelaskan dalam buku ini, diharapkan dapat membantu memenuhi kebutuhan tersebut. Belajar bersama, yang diawali dalam kegiatan terstruktur, diharapkan bisa dilanjutkan di tempat masing-masing untuk mendorong perubahan sosial, khususnya dalam rangka membangun pengelolaan sumberdaya alam berkelanjutan.

Buku ini menyajikan cerita bagaimana CIFOR (Center for International Forestry Research) bersama PILI (Pusat Informasi Lingkungan Indonesia-PILI NGO Move), mengembangkan pendekatan pembelajaran bersama, yang kemudian dikenal sebagai Shared Learning (SL), sekaligus menguraikan langkah-langkah untuk melaksanakan kegiatan serupa.

Meskipun demikian, kami menekankan, bukan struktur atau bentuk yang menjamin keberhasilan belajar tetapi isi dan fasilitasi. Karena itu, buku ini saja belumlah cukup untuk melaksanakan kegiatan pembelajaran bersama. Pun, pustaka ini juga baru menuangkan sebagian pengalaman, separuh refleksi, dan sejumlah serpihan pengetahuan yang bisa dipetik dalam menggelar SL.

Bacaan ini ditujukan kepada pihak-pihak yang berniat baik untuk menebar benih pembelajaran bersama, apapun bentuknya, dan diarahkan untuk membantu pihak yang sudah terlibat dalam usaha mencari pola tata kelola sumberdaya alam bersama pihak lain, atau pihak yang ingin memperluas cakupan dampak kegiatannya.

SL yang sudah dilaksanakan sebanyak tujuh kali ini, ternyata sangat diminati oleh para pesertanya. "Kalau kami tak diundang, kirimkan hasilnya," demikian sebuah surat menyurat singkat (SMS) dari kawan alumni SL asal Jambi kepada tim penyelenggara saat menggelar forum SL V di Yogyakarta, akhir tahun 2006.

Semoga buku ini bermanfaat. 


\section{Tabur Kasih}

Sebelum buku ini ditulis dan diterbitkan, sebuah perjalanan panjang proses pembelajaran bersama telah ditempuh. Hikmah yang tertuang dalam catatan ini merupakan buah dari tujuh rangkaian Shared Learning (SL). Sebagai ajang akbar, SL tak akan pernah terwujud-artinya, buku ini juga tak akan pernah lahirtanpa sumbangan pikiran dan tenaga dari berbagai pihak, baik individu, lembaga maupun masyarakat.

Masih hangat di benak kami kenangan dan keterbukaan berbagai masyarakat di mana SL dilaksanakan. Kami mengucapkan banyak terima kasih kepada seluruh masyarakat di mana SL pernah digelar, yang tersebar mulai dari Tangkahan, sekitar Taman Nasional Gunung Leuser, Sumatera Utara, hingga ujung timur, Sumba, Nusa Tenggara Timur.

Menengok kembali tema-tema pembelajaranSL, mewajibkan kami untuk berterima kasih pula kepada para narasumber dan reviewer yang telah menyebar bibit ilmu pengetahuan baru kepada seluruh peserta, tim fasilitator dan penyelenggara SL.

Sebagai kegiatan yang merangkai beragam pengetahuan, kami berterima kasih secara mendalam kepada, sedikitnya, 250 pembelajar yang telah bertukar pengalaman dan pengetahuan selama SL diselenggarakan. Mulai dari Nanggro Aceh Darussalam hingga Lampung, kami menyebarkan rasa terima kasih bagi peserta yang berasal dari Sumatera. Dari ujung barat Pulau Jawa hingga ujung timur Nusa Tenggara, dengan tulus kami tabur rasa terima kasih untuk pembelajar yang tersebar di wilayah ini. Tak lupa, ucapan terima kasih bagi peserta dari Pulau Kalimantan, mulai dari Danau Sentarum, Kalimantan Barat, sampai Desa Setulang, Malinau, Kalimantan Timur. Peserta yang berasal dari jazirah Sulawesi hingga Papua tak luput pula dari sentuhan rasa terima kasih dari kami.

Kegiatan SL juga tak akan terselenggara dengan baik tanpa sumbangan pikiran dan tenaga dari rekan-rekan di CIFOR: Imam Basuki, Meilinda Wan, Michael Padmanaba, Elizabeth Linda Yuliani, Heru Komarudin, Nugroho Adi, Yayan Indriatmoko, dan Yulia Siagian. Rekan-rekan dari PILI juga telah banyak memberi andil besar bagi kegiatan SL dan penulisan buku ini. Eka Muliawati Putri, Widiyanto, dan Lidya Ariesusanti, yang tak kenal lelah terus mengawal penyelenggaraan seluruh seri SL. 
Terakhir, seluruh aktivitas belajar bersama dalam forum SL tak akan terselenggara tanpa bantuan dari Ford Foundation. Dukungan yang diberikan lembaga ini telah membuka ruang pembelajaran bersama bagi semua pihak, terutama melalui forum SL ini.

Bogor, Januari 2008 


\section{Belajar sambil Mengajar}

ajar $n$ petunjuk yg diberikan kpd orang supaya diketahui (diturut);

bel.a.jar $v 1$ berusaha memperoleh kepandaian atau ilmu: adik membaca; 2 berlatih: ia sedang mengetik; murid-murid itu $\sim$ karate; 3 berubah tingkah laku atau tanggapan yg disebabkan oleh pengalaman;

mem.bel.a.jar.kan $v$ menjadikan bahan atau kegiatan belajar;

pem.bel.a.jar $n$ orang yg mempelajari;

pem.bel.a.jar.an $n$ proses, cara, perbuatan menjadikan orang atau makhluk hidup belajar;

pe.mel.a.jar.an $n$ proses, cara, perbuatan mempelajari;

meng.a.jar $v 1$ memberi pelajaran: guru $\sim$ murid matematika; 2 melatih: ia berenang; Kakak menari; 3 memarahi (memukuli, menghukum, dsb) supaya jera; meng.a.jari $v 1$ mengajar kpd: guru $\sim$ siswa berbaris; ayah $\sim$ adik naik sepeda

Kamus Besar Bahasa Indonesia, Edisi Ketiga, Cetakan Kedua, Pusat Bahasa Departemen Pendidikan Nasional, Balai Pustaka, 2002. 


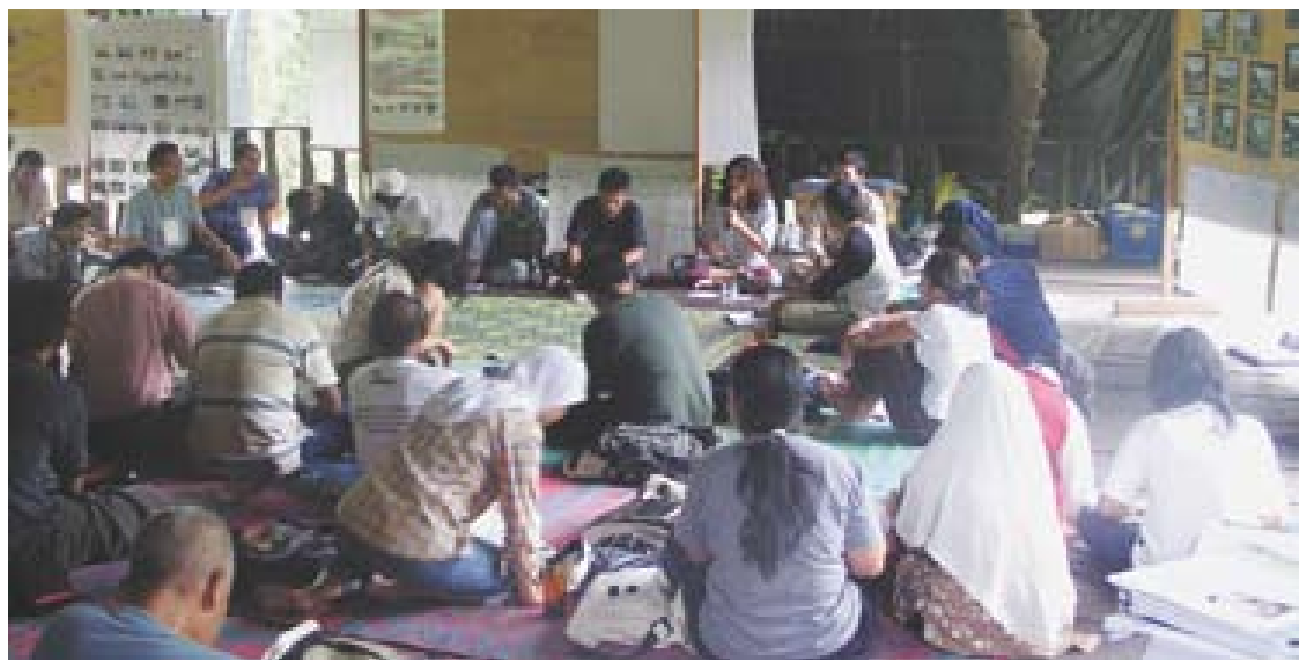

Shared Learning menjadi forum belajar bersama bagi para pihak.

Dari sini, diharapkan cakupan proses belajar meluas ke arah pembelajaran sosial. 


\section{BAB I}

\section{Shared Learning: Konsep dan Praktik dalam Pengelolaan Hutan Multipihak di Indonesia}

Memahami adalah melihat dari bawah, cara terbaik untuk memahami adalah datangi rakyat, tinggal bersama mereka, belajarlah dari mereka, cintai mereka mulailah dari apa yang mereka ketahui, bangunlah dengan apa yang mereka miliki. Tetapi jika menjadi pemimpin yang terbaik, setelah kerja keras selesai, dan tujuan tercapai rakyat akan berkata, "Kita telah melakukannya sendiri." (Filsuf Cina).

\section{Pendahuluan}

Masa depan hutan dan kehutanan Indonesia kian suram. Dalam sepuluh tahun terakhir, laju deforestasi meningkat tajam. Food and Agriculture Organization (FAO) menyebutkan, angka penyusutan sudah mencapai 1,87 juta hektar per 
tahun dan menempatkan Indonesia sebagai negara tercepat kedua dalam deforestasi setelah Brazil, yang mencapai 3 juta hektar per tahun (Kompas, 6 Januari 2007). Kini, dari kawasan hutan seluas 120 juta hektar, kurang dari separuhnya yang masih berhutan.

Hutan tropis Indonesia yang kaya, dan telah menopang kehidupan puluhan juta penduduk di dalam dan sekitar hutan dengan menyediakan berbagai keuntungan, akan segera tinggal cerita akibat salah urus pengelolaannya. Banyaknya pihak yang berkepentingan pada kawasan hutan yang sama mengakibatkan tingginya sengketa atas penguasaan dan kepemilikan lahan, alih fungsi hutan, kebakaran serta pembalakan liar. Kerugian akibat pencurian kayu saja mencapai Rp. 30 triliun dengan total kayu tercuri sebesar 70 juta meter kubik pertahun (Kompas, 6 Januari 2007), belum terhitung pula kerugian yang ditanggung masyarakat akibat rusaknya lingkungan. Pengelolaan hutan oleh Pemerintah Indonesia yang sentralistik (top-down approach) maupun sistem pengelolaan oleh masyarakat lokal, dan kelembagaannya, tidak mampu mencegah laju kerusakan hutan.

Menyadari kelemahan pengelolaan hutan di masa lalu dan mengakui banyaknya pihak yang berkepentingan, sejak awal Reformasi 1998 mulai digulirkan sistem kehutanan multipihak. Pendekatan ini dianggap mengedepankan pemerataan dan keadilan dalam pengaturan dan pengurusan hutan serta distribusi manfaatresikonya. Pendekatan ini juga mendasarkan diri pada prinsip-prinsip demokrasi dan partisipasi (Fahmi dan Zakaria, 2003). Kendati sejumlah pertanyaan layak diajukan, namun pendekatan multipihak diyakini mampu mempertemukan dan menyeimbangkan berbagai kepentingan atas pengelolaan hutan.

Akan tetapi, pengelolaan hutan multipihak ternyata belum cukup mampu membawa kebaruan pengetahuan dan kapasitas bagi dua sistem pengelolaan oleh pemerintah dan masyarakat itu. Yang terjadi justru sebaliknya, koordinasi yang lemah, keterikatan para pihak pada kepentingan sesaat, maupun kolaborasi yang kehilangan relevansinya karena kondisi yang telah berubah. Akibatnya, keputusan yang dihasilkan tidak optimal dan cenderung mengabaikan potensi bagi penyelesaian masalah secara adaptif, kreatif dan capaian yang inovatif.

Sikap adaptif dapat dikembangkan melalui proses belajar yang sadar dan terus menerus dengan memanfaatkan beragam perspektif dan pengetahuan-nilai, kapasitas, perspektif, metode belajar, tempat, dan pengalaman sejarah-yang dibawa dalam proses multipihak. Pengetahuan dan pengalaman adalah aset bagi penyelesaian masalah, jika dibagi bersama-sama. Sebaliknya, bila diabaikan akan merugikan banyak pihak. 
Pembelajaran bersama mendorong persepsi soal saling ketergantungan dan saling menghargai di antara pemangku kepentingan. Selain itu, penekanan pada pembelajaran bersama juga membantu para pihak untuk terus beradaptasi terhadap dinamika perubahan sosial dan lingkungan.

Program pembelajaran bersama bukanlah hal baru. Sekolah lapang dan inisiatif pembelajaran partisipatif telah berkembang selama beberapa dasawarsa terakhir. Banyak kalangan telah melaksanakan program pembelajaran, antara lain, Program Kehutanan Multipihak (MFP-DfID/Departemen Kehutanan), Jaringan NTFP (Non-Timber Forest Product), Konsorsium pendukung Sistem Hutan Kerakyatan (KpSHK), Lingkaran Pembaruan Desa dan Agraria (KARSA), dan Konsorsium Pengembangan Masyarakat Nusa Tenggara (KPMNT).

Pada dasarnya, semua prakarsa ini untuk mendorong pembelajaran sosial, dan kelompok, secara lebih efektif. Pendekatan CIFOR (Center for International Forestry Research) dan PILI (Pusat Informasi Lingkungan Indonesia-PILINGO Movement) yang ditawarkan di sini mempunyai keistimewaan karena digunakan, terutama, sebagai alat pemberdayaan dan membangun kepercayaan diri. Ketrampilan dan pengetahuan semua pihak diakui, dan dihargai secara khusus sebagai bahan pelajaran utama. Hal khusus lainnya, pembelajaran yang dikembangkan menjalin pengalaman dan pengetahuan dari beragam proyek, lokasi, maupun latar belakang pihak yang berbeda-beda.

\section{Tujuan Buku}

Bacaan ini berupaya mendudukkan Shared Learning (SL) sebagai konsep dan praktik berdasarkan pengalaman CIFOR bersama PILI, serta maknanya dalam mendorong perubahan sosial pada sektor kehutanan di Indonesia. Berlarik-larik tulisan dalam buku ini berusaha memberikan kerangka teoritis dan nilai penting SL dalam pengelolaan sumberdaya alam. Selain itu, buku ini juga berikhtiar untuk memberikan panduan singkat bagi mereka yang berminat mengembangkan SL secara lebih luas.

Tulisan ini menjadi penting, khususnya dalam konteks pengelolaan sumberdaya hutan, mengingat masih jarangnya kerangka teoritis dan praktis pembelajaran bersama yang dapat diterapkan dalam konteks Indonesia. Kendati buku ini akan memberikan panduan praktis, namun tidak dimaksudkan untuk diterapkan secara kaku. Bahkan, sangat terbuka untuk dikembangkan sesuai dengan konteks dan 
tujuan pengguna. Pustaka ini sangat terbuka lebar untuk diadopsi dan diadaptasi dalam berbagai kondisi, skala, dan tema pembelajaran yang beragam.

Catatan ini diharapkan dapat membantu para pengembang jaringan pembelajaran, para individu dan lembaga-lembaga pembelajaran, pimpinan dan staf lembaga pendamping masyarakat, lembaga swadaya masyarakat (LSM), pemerintah, penentu kebijakan, perguruan tinggi, lembaga penelitian, mahasiswa, guru, dan khalayak umum.

\section{Belajar Bersama}

Kehidupan senantiasa memperlihatkan kompleksitas dan perubahan: sistem ekologi dan sumberdaya alam merupakan sistem yang dinamis, berubah-ubah, rumit, dan penuh ketidakpastian. Kerumitan ini diperparah oleh kepentingan dan pemanfaatan sumberdaya alam yang juga berubah seiring meningkatnya jumlah pemakai serta berkembangnya pengetahuan. Akan tetapi, sementara pengetahuan untuk memanfaatkan sumberdaya alam terus berkembang, pengetahuan mengenai sistem kehidupan masih terbatas.

Hal ini tercermin dalam potret kehutanan Indonesia sebagaimana telah diungkapkan di atas. Dalam semangat demokratisasi yang kian berkembang, arah perubahan itu semestinya buah dari keputusan dan tindakan bersama. Karena itu, dalam menghadapi perubahan yang serba cepat, dan kurangnya pengetahuan mengenai sistem hutan, dibutuhkan sikap yang adaptif, lentur dan kreatif.

Untuk itu dibutuhkan kesediaan untuk terus belajar, termasuk mempelajari pengelolaan yang sedang dilaksanakan dan bila diperlukan, memperbaikinya. Sayangnya, selama ini, media pembelajaran bersama bagi para pemangku kepentingan dalam pengelolaan hutan di Indonesia masih kurang diperhatikan. Padahal, belajar bersama menjadi dasar untuk mendorong kolaborasi atau memicu kelompok-kelompok yang berkepentingan secara kolektif lebih bertanggung jawab dalam mengelola hutan.

Untuk mendorong proses pembelajaran sosial tersebut, CIFOR dan PILI mengembangkan suatu pendekatan pembelajaran bersama yang disebut Shared Learning (SL). SL dirancang untuk mendorong perubahan sosial melalui pengembangan sikap, cara pandang, pengetahuan, dan ketrampilan, dengan tujuan khusus: 
- Membangun forum pertukaran dan berbagi pengalaman serta pengetahuan,

- Membangun proses belajar yang lebih partisipatif,

- Membangun proses multipihak bagi perubahan sosial,

- Membangun jaringan,

- Membantu menjembatani antara realitas lokal dengan kebijakan nasional.

Pendekatan SL itu sendiri berangkat dari hasil dua program kaji tindak (action research) yang dilakukan oleh CIFOR.

Kajian pertama berupa kegiatan konsultasi multipihak untuk mendorong perubahan kebijakan, mulai dari desa hingga kabupaten. Sejumlah pertemuan pada beberapa tingkat (desa, kabupaten dan provinsi) dilaksanakan dengan maksud mempersatukan berbagai pihak yang berkepentingan dalam pengelolaan sumberdaya alam. Pertemuan-pertemuan formal tersebut bermanfaat sebagai ajang komunikasi sehingga para pihak lebih mengenal kepentingan pihak lain. Hanya saja, forum-forum tersebut tidak banyak menyediakan peluang bagi refleksi bersama.

Kedua, kaji tindak pengelolaan hutan bersama secara adaptif (Adaptive Collaborative Management/ACM). ACM terdiri dari siklus-siklus adaptif yang dilakukan secara kolaboratif dengan melibatkan semua pemangku kepentingan. Kunci pengelolaan hutan bersama masyarakat bertumpu pada proses belajar yang terdiri dari: refleksi, adaptasi/penyesuaian dan aksi. Secara sederhana, ACM dapat digambarkan sebagai proses yang mencakup (Kusumanto dkk, 2006):

- Interaksi di antara para pemangku kepentingan,

- Komunikasi dan pembelajaran di antara para pemangku kepentingan,

- Tindakan bersama yang menghasilkan perubahan atau penyesuaian pengelolaan.

Termasuk dalam kegiatan ACMadalah usaha mempengaruhi kebijakan pengelolaan sumberdaya hutan yang didukung oleh masyarakat. Pembelajaran khusus di bidang kebijakan, tentunya mensyaratkan keterlibatan pihak-pihak lain. Usaha ini, pada awalnya, dilaksanakan melalui pelatihan penyusunan peraturan perundangan di tingkat kabupaten dengan melibatkan masyarakat. Forum berbentuk pelatihan, dengan tujuan tertentu, memang tepat untuk meningkatkan kemampuan para pesertanya, tetapi kurang menyediakan peluang untuk memahami kepentingan pihak lain maupun perubahan sikap atau nilai. 
Program SL berawal dari dua kegiatan yang dimaksudkan untuk mendukung program pengelolaan hutan multipihak di Malinau dan Jambi:

- Kunjungan staf Pemerintah Daerah Malinau—dan beberapa kepala desa, Kalimantan Timur, ke Desa Baru Pelepat, Kabupaten Bungo, Jambi, untuk mempelajari pendekatan partisipatif dalam pembentukan Badan Perwakilan Desa (BPD),

- Satu pelatihan penyusunan peraturan tingkat desa di bidang tata ruang yang dilaksanakan di Desa Sengayan, Kabupaten Malinau, Kalimantan Timur.

Lawatan silang orang Malinau ke Jambi merupakan pengalaman yang menarik ketika interaksi antar-individu dari latar belakang dan daerah yang berbeda, secara nyata, membuat orang berpikir. Hal-hal yang dianggap biasa bagi orang setempat, ternyata menjadi sesuatu yang unik untuk sang pelawat sehingga membuat tuan rumah maupun pelawat berpikir. Contohnya, lubuk larang-semacam jeda pemanenan ikan di bagian tertentu sebuah sungai-yang banyak dijumpai di Bungo, namun tidak dijumpai di Malinau.

Sebagai balasan, ketika ada pelatihan penyusunan peraturan desa di Malinau, mitra dari Baru Pelepat diundang. Untuk memenuhi janji kepada mitra di Manggarai, Flores, Nusa Tenggara Timur (NTT), beberapa orang dari sana pun turut diundang. Hasilnya, sangat menggembirakan. Adanya peserta dari tempat lain yang membawa pengalaman unik membuat diskusi lebih hidup. Dan, sekali lagi, membuat orang setempat berpikir tentang hal-hal yang dianggap biasa. Hutan yang luas dan lebarnya sungai di Malinau membuat orang NTT terheran-heran dan menyadarkan orang Malinau akan kekayaan alamnya.

Dari dua pengalaman ini berkembanglah program pembelajaran bersama atau SL ini. Arena belajar SL merupakan hasil persilangan antara lokakarya, pelatihan dan diskusi kelompok terarah (focused group discussion/FGD) dengan berlandaskan pada model pembelajaran orang dewasa. Forum SL pertama dilaksanakan bersama KOPPESDA (Koordinasi Pengkajian Pengelolaan Sumberdaya Alam), Sumba, sedangkan putaran SL berikutnya hasil kerja sama CIFOR dengan PILI. Berikut ini serial SL secara menyeluruh:

- SL I: Monitoring dan Evaluasi Kolaboratif, Taman Nasional LaiwanggiWanggameti, Sumba, Nusa Tenggara Timur,

- SL II: Pengelolaan Kolaboratif untuk Kawasan Konservasi, sekitar Taman Wisata Alam Gunung Pancar, Bogor, dan Hutan Lindung Gunung Simpang, Cianjur, Jawa Barat, 
- SL III: Manajemen Konflik dalam Pengelolaan Sumberdaya Alam, Taman Nasional Gunung Leuser, Tangkahan, Sumatera Utara,

- SL IV: Kemitraan dalam Pengelolaan Hasil Hutan Bukan Kayu, Tomohon, Sulawesi Utara,

- SL V: Kemitraan dalam Pengelolaan Sumberdaya Air, sekitar Taman Nasional Gunung Merapi, Yogyakarta,

- SL VI: Kemitraan dalam Penyusunan Tata Ruang, Taman Nasional Gunung Halimun-Salak, Sukabumi, Jawa Barat,

- SL VII: Kewirausahaan Sumberdaya Alam yang Ramah Lingkungan, seputar Taman Nasional Gunung Gede Pangrango, Cianjur, Jawa Barat.

\section{Shared Learning sebagai Pendekatan Pembelajaran Sosial}

Sebagaimana telah disebutkan sebelumnya, salah satu kunci keberhasilan mengembangkan proses adaptif yang mengarah pada peningkatan kemampuan dalam pengelolaan hutan adalah belajar dan, secara khusus, pembelajaran sosial. Pembelajaran sosial dalam hal ini adalah pembelajaran yang terjadi dalam sekelompok orang melalui interaksi sosial, bukan proses belajar yang dialami oleh masing-masing orang secara terpisah.

Pembelajaran bersama merupakan tulang punggung dari pendekatan ACM. Pembelajaran berlangsung melalui interaksi sosial di antara beberapa individu atau kelompok berlainan yang memungkinkan pencapaian pengetahuan baru. Meskipun pengetahuan baru dapat juga diperoleh dengan cara belajar secara mandiri, menurut Wollenberg dkk. (2000), belajar secara interaktif lebih menguntungkan karena adanya tambahan pengetahuan dari orang atau pihak lain. Belajar bersama juga memungkinkan koordinasi-diperlukan untuk mentransformasikan informasi menjadi pengetahuan baru, mengingat, setidaknya ada dua pihak yang terlibat dalam proses pembelajaran. Pada sisi lain, disadari, pembelajaran sosial memerlukan waktu dan biaya yang lebih banyak karena harus mempertemukan sejumlah orang beserta buah pemikirannya.

Forum SL diharapkan dapat mendorong proses multipihak dalam menangani permasalahan kehidupan, kelestarian hutan, kompleksitas pihak yang 
berkepentingan, dan sistem pengelolaan yang tidak efektif dalam menghadapi perubahan yang cepat ${ }^{1}$.

Agar kegiatan ini terfokus dan terkait dengan program ACM maka pembelajaran diarahkan pada pengelolaan bersama sumberdaya hutan. Forum SL diusahakan sebagai proses yang mendorong pengembangan, pemanfaatan, berbagi informasi dan pengetahuan; juga, memperkuat pengetahuan para pihak melalui refleksi terarah. Lebih utama lagi, SL dimaksudkan untuk mendorong pembelajaran di dalam dan di antara kelompok yang beragam demi menyokong perubahan sosial.

Sejumlah indikator bisa dijadikan petunjuk tentang telah terjadinya pembelajaran sosial: perubahan dalam pemahaman, persepsi, tingkah laku, tindakan kelompok, dan sebagainya. Untuk lokasi tertentu akan diperlukan beberapa indikator yang sesuai dengan keadaan setempat; misalnya, cara-cara kelompok mengkaji atau menanggapi informasi baru berkaitan dengan lokasi itu.

Untuk membangun minat belajar para pemangku kepentingan serta memastikan pembelajaran sosial akan terjadi, sedikitnya, ada tiga elemen yang diperlukan:

- Pokok atau fokus persoalan yang jelas,

- Gagasan atau informasi baru,

- Forum atau basis untuk berkomunikasi.

Sebagai bagian dari metode pembelajaran sosial, belajar bersama adalah proses kolektif untuk mengumpulkan pengetahuan baru oleh sebuah kelompok sosial tertentu. Melalui kegiatan ini akan terlihat bagaimana pengetahuan dikembangkan, dan disebarkan antar-kelompok, kemudian membangun motifmotif segar bagi aksi-aksi dan pola-pola interaksi baru. Belajar bersama juga merujuk pada kerangka kerja untuk pengelolaan konflik, kebijakan publik dan pengambilan keputusan. Pembelajaran bersama mengakui, setiap kelompok kepentingan membawa pengetahuan yang berbeda, meliputi nilai-nilai, kapasitas, perspektif, metode, dan pengalaman sejarah, dalam proses interaksinya.

Pembelajaran bersama merupakan turunan dari pendekatan-pendekatan partisipatif yang berkembang dalam dua dekade terakhir. Rapid Rural Appraisal (RRA), yang muncul pada tahun 1970-an, adalah cara belajar yang dilakukan oleh orang dari luar-umumnya, tentang sistem pertanian, secara efisien dan

1 Dalam Proyek ini, proses pembelajaran sosial dilakukan melalui fasilitasi atau pendampingan, khususnya untuk menguatkan kapasitas multipihak tingkat desa. Karenanya, dalam proyek ini juga digunakan istilah penelitian-pendampingan. 
efektif dalam hal biaya dan waktu. Hal ini dimungkinkan dengan melakukan survei berskala besar, melibatkan masyarakat setempat, dan memanfaatkan serangkaian metode pengumpulan data yang partisipatif. Kelemahan dari RRA ini, proses belajar diarahkan dan hanya untuk kepentingan peneliti, bukan untuk masyarakat atau pihak lain yang terlibat.

Pendekatan Participatory Rural Appraisal (PRA), atau pemahaman desa secara partisipatif, muncul pada tahun 1980-an. Pendekatan ini merupakan pengembangan dari RRA dengan menekankan pada aspek penguatan masyarakat, penghargaan pada pengetahuan lokal, penekanan pada konteks lokal, kenyamanan dan inklusif. Meskipun dalam PRA interaksi antara masyarakat dengan peneliti sudah sangat terbuka, namun posisi peneliti masih tetap mengambil peran besar dalam proses belajar.

\section{Shared Learning, sebuah Praktik}

Kegiatan SL dikembangkan sebagai sarana saling belajar antarpihak yang berkaitan dengan pengelolaan hutan dan kawasan oleh masyarakat. Kegiatan ini mengacu pada tiga dimensi yang menjadi inti pembelajaran, yaitu: pengembangan pengetahuan, ketrampilan, serta sikap atau nilai-nilai. Dari kegiatan ini akan dipetik hikmah belajar (lessons learned) yang akan menjadi acuan utama dalam mengembangkan aksi-aksi baru yang lebih baik.

Menyadari perbedaan cara, gaya, dan kemampuan belajar individu, forum SL, sebagai sebuah praktik, mengombinasikan berbagai model belajar yang berkembang dalam 10 tahun terakhir, yaitu:

- Pembelajaran Orang Dewasa (andragogy). Model pembelajaran orang dewasa berbeda dengan pembelajaran pada anak-anak. Pada pembelajaran anak-anak, peserta dipandang sebagai makhluk yang bergantung, sementara untuk orang dewasa dipandang sebagai makhluk yang mampu mengatur dan menentukan dirinya sendiri. Berbeda dengan cara belajar anak-anak, yang mendapatkan jawaban dari orang lain atas pertanyaan yang diajukannya, orang dewasa mampu membangun pertanyaan dan sekaligus menjawab berdasarkan pengalamannya. Prinsip-prinsip penting dalam andragogy: partisipatif (bukan pasif), beranjak dari pengalaman, reflektif, memenuhi kebutuhan langsung, untuk diri sendiri, menghargai mereka yang belajar, memberikan umpan-balik, menciptakan suasana aman dan berlangsung dalam suasana yang nyaman, 
- Appreciative Inquiry (AI). Berbeda dengan bentuk intervensi perubahan organisasi yang lain, AI menolak pendekatan pemecahan masalah (problem solving approach) karena bersifat menyakitkan, jarang menghasilkan visi baru, memunculkan sikap defensif serta membuat rasa tidak percaya diri untuk melakukan tindakan positif. Asumsi dasar AI: organisasi bukanlah persoalan yang harus diselesaikan tetapi pusat kapasitas hubungan tanpa batas, hidup dengan imajinasi tak terhingga, terbuka, tak tentu; dan, pada dasarnya organisasi merupakan sebuah misteri (Cooperrider dan Srivasta, 1987). AI menggali yang terbaik dari pengalaman individu guna menyediakan sebuah kekuatan untuk mengimajinasikan apa yang mungkin terjadi. AI memandang suatu fenomena lebih positif sebagai pijakan untuk mencapai tujuan atau visi yang lebih tinggi. AI adalah sebuah metode yang mentransformasikan kapasitas sistem manusia untuk perubahan positif dengan menekankan pengalaman positif dan masa depan yang penuh harapan. Langkah dasar AI adalah siklus 5-D: Definition, Discovery, Dream, Design, dan Destiny (Whitney dan Bloom, 2007),

\section{Kotak 1. Siklus 5 D Appreciative Inquiry]}

a. Definition. Langkah awal $A l$ adalah memilih sebuah topik yang akan dieksplorasi (affirmative topic choice). Topik ini menjadi arah perubahan sekaligus kenyataan akhir yang akan terwujud.

b. Discovery. Tujuan utamanya, mengungkap dan menghargai sesuatu yang memberi kehidupan dan energi kepada orang, pekerjaan dan organisasi. Tahap ini berfokus pada cerita positif yang merefleksikan pengalaman puncak, baik pada tingkat individu maupun organisasi. Pada tahap ini, peserta berbagi cerita positif, mendiskusikan kondisi positif organisasi dan mengkaji aspek paling berharga dalam sejarah mereka yang ingin dikembangkan di masa depan.

c. Dream. Bermimpi (dream) atau berimajinasi (envision) tentang kondisi ideal organisasi di masa depan. Informasi pada tahap sebelumnya dijadikan pijakan untuk berspekulasi mengenai kemungkinan masa depan organisasi.

d. Design. Bertujuan untuk menciptakan atau merancang struktur organisasi, proses dan hubungan yang mendukung mimpi yang telah diartikulasikan pada tahap sebelumnya. Aktivitas utamanya, menciptakan proposisi yang provokatif (provocative propositions) secara kolaboratif. Proposisi yang provokatif dapat dipandang sebagai mimpi yang realistis yang memberdayakan sebuah organisasi mencapai sesuatu yang lebih baik.

e. Destiny. Tahap ini bertujuan menguatkan kapasitas dukungan terhadap keseluruhan organisasi untuk membangun harapan, menciptakan proses belajar, adaptif dan berimprovisasi. Tahapan ini memberdayakan setiap peserta untuk melakukan tindakantindakan yang dapat dilakukan untuk mencapai mimpi atau visi masa depan.

Sumber mengenai Al: http://appreciativeinquiry.cwru.edu/ 
- Experiental Learning. Model ini memandang pembelajaran dari pengalaman, dan merefleksikannya, menjadi cara belajar yang efektif bagi multpihak untuk meningkatkan pengetahuan, sikap dan ketrampilannya. Model ini mengikuti siklus belajar: mengalami — mengurai — menganalisis - menyimpulkan,

- Accelerated Learning. Model ini adalah hasil pengembangan dari berbagai ilmu lainnya, di antaranya, ilmu kognisi modern. Ilmu kognisi modern menunjukkan, belajar yang efektif bukan semata-mata bersifat verbal dan kognitif, tapi juga reflektif, terbuka, melibatkan emosi, seluruh tubuh dan indera. Model ini juga memahami, setiap orang memiliki gaya belajar yang berbeda-beda. Beberapa prinsip belajar yang diterapkan: belajar melibatkan seluruh pikiran dan tubuh; belajar adalah berkreasi dan mencipta, bukan hanya menyerap materi; kerja sama membantu proses belajar; pembelajaran berlangsung pada banyak tingkatan dan simultan; belajar paling baik adalah belajar dalam konteks; emosi positif sangat membantu pembelajaran; serta, bentuk visual lebih kuat untuk ditangkap informasinya.

Kombinasi ini penting untuk mengefektifkan proses pembelajaran sepanjang kegiatan SL. Proses pembelajaran SL merupakan ramuan dari berbagai model pembelajaran tersebut di atas.

Selain itu, aksi kolektif juga menjadi penting dalam proses pembelajaran agar perubahan yang diharapkan bisa terjadi pada skala yang lebih luas. Dan, pada kenyataannya, selama ini pengelolaan hutan dan kawasan oleh masyarakat berjalan sendiri-sendiri. Akibatnya, proses pembelajaran sangat kurang dan belum mampu menggerakkan perubahan kebijakan secara nyata, baik di tingkat pemerintah daerah, provinsi maupun pusat.

Melalui pendekatan pembelajaran bersama, para pihak dari berbagai wilayah dipertemukan untuk meningkatkan skala pembelajaran: dari antar-individu dan kelompok kepada antar-program atau antar-kawasan/wilayah dan mengembangkan jaringan pembelajaran. Proses belajar SL tertuju pada aspek-aspek penting dalam pengembangan pengelolaan hutan oleh rakyat yang mencakup prinsip konservasi, kesejahteraan, sosial-budaya, serta kolaborasi. 


\section{Prinsip-prinsip Utama Shared Learning}

Sebenarnya, istilah 'shared learning' berkembang secara spontan karena menekankan aspek berbagi dan belajar dari pengalaman pembelajar. SL juga dikembangkan untuk menanggapi adanya kelemahan dari forum pelatihan, lokakarya, dan kunjungan silang, di mana peserta digiring menuju pemahaman atas bahan-bahan yang disajikan oleh pelatih atau narasumber. Maka, prinsip utama SL adalah pemerataan kesempatan untuk berbagi pengalaman dan pengetahuan bagi semua pihak ('levelling the playing field') serta menyalurkan informasi secara horizontal.

Prinsip atau nilai yang menjadi landasan berpijak dalam proses pembelajaran dikembangkan seiring dengan terselenggaranya seri-seri SL. Selain itu, hasil Lokakarya Nasional tentang Pembelajaran Sosial dalam Pengelolaan Sumberdaya Alam, Juli 2006, menghasilkan beberapa prinsip penting, yaitu:

- Semua peserta adalah guru dan semua peserta adalah murid. Prinsip ini berangkat dari pemikiran Freire tentang proses belajar. Dalam konteks ini, kian majemuk pembelajar SL akan semakin baik dalam mendukung proses pembelajaran. Setiap peserta akan menjadi 'murid' untuk mempelajari hal-hal yang tidak diketahuinya dan menjadi 'guru' untuk mengajarkan hal-hal yang dipahaminya: belajar sambil mengajar.

- Semua tempat adalah ruang belajar. Pembelajaran tidak hanya berlangsung dalam ruangan, tetapi dapat dilakukan di mana dan kapan saja. Proses pembelajaran akan semakin efektif ketika setiap hikmah yang dipetik dipahami sesuai dengan konteksnya.

- Semua pengalaman adalah bahan pembelajaran. Dalam pendidikan orang dewasa, pengalaman menjadi unsur penting sebagai materi pelajaran. Keberagaman latar belakang-lembaga, budaya, pengalaman, tujuan, termasuk keberagaman minat dan kebutuhan (teori dan praktik), akan menjadi bahan pembelajaran yang penting.

- Belajar secara sadar dan sungguh-sungguh. Prinsip ini juga didasari gagasan Freire: belajar yang membebaskan akan terjadi bila dilakukan secara sadar, dan penuh kesadaran. Sadar, artinya, dilakukan secara sengaja dan atas keinginan pembelajar sendiri; penuh kesadaran berarti proses belajar dan pengetahuan yang diperoleh juga dipahami serta diyakini, lalu diterapkan dalam tindakan baru.

- Berorientasi pada perubahan. Setiap peserta harus secara sadar dan sungguh-sungguh berpartisipasi dalam proses pembelajaran untuk melakukan perubahan-perubahan yang dibutuhkan—sikap, wawasan, 
ketrampilan, dan sebagainya, bagi dirinya sendiri dan membantu perubahan kolektif.

- Keterbukaan. Setiap pihak bersedia membuka diri untuk berbagi pengalaman yang dimilikinya dan mengenali - memahami - menerima pengalaman/pemikiran pihak lain. SL diselenggarakan secara terbuka bagi pihak lain, pihak kawan (seideologi) maupun lawan (ideologi berseberangan), bersikap inklusif dan mengakui kemajemukan.

- Keseimbangan teori dan praktik. Dalam pembelajaran yang berbasis pengalaman, penting untuk memperhatikan keseimbangan antara teori dan praktik. Proses belajar dalam SL memungkinkan bagi para praktisi untuk memahami teori, atau berpraktik sambil berteori. Dan sebaliknya, juga mempraktikkan teori. 


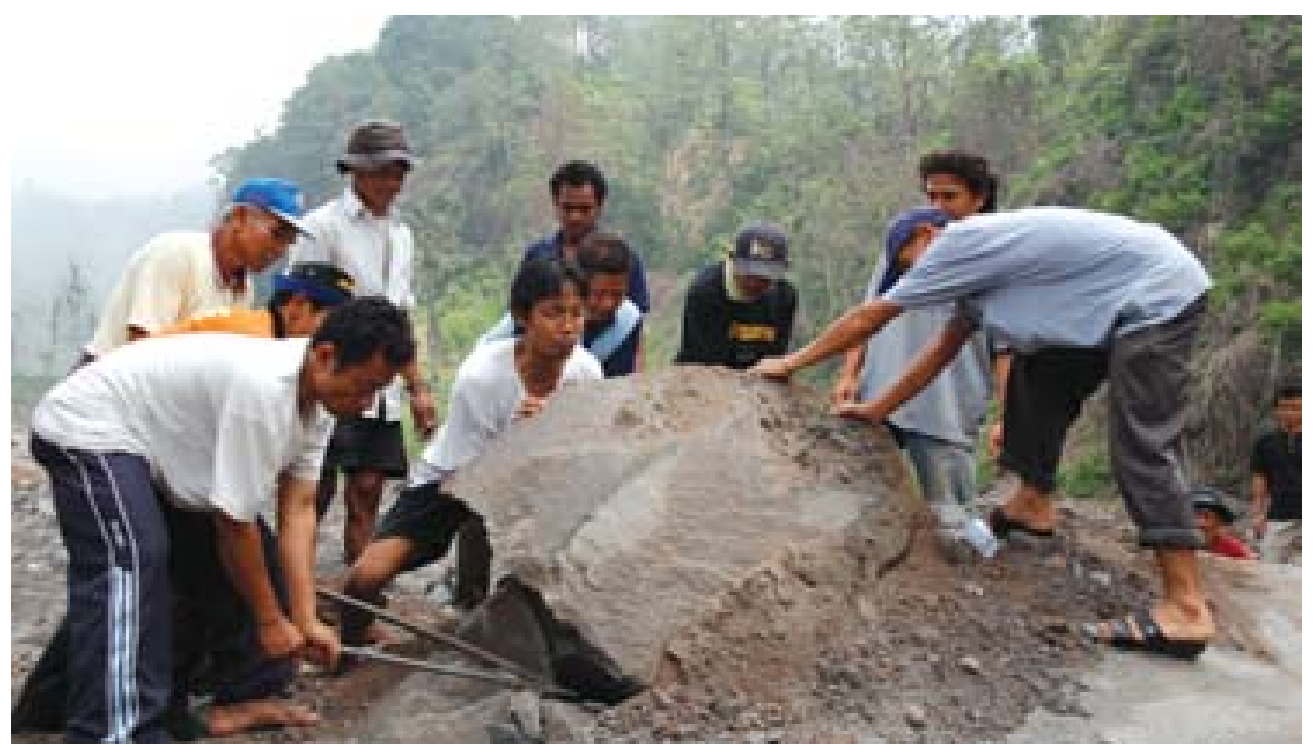

Agar berhasil merangkai berbagai pengalaman dan melintasi beragam tempat belajar, penyelenggaraan forum $S \mathcal{L}$ harus didukung oleh tim yang mampu bekerja sama dan kompak. 


\section{BAB II}

\section{Tiga Langkah Meracik Shared Learning}

Pada awalnya, kegiatan Shared Learning (SL) ditujukan untuk mendukung penelitian ACM, sehingga pengelolaan bersama sumberdaya hutan ditetapkan sebagai tema payung. Lantas, tema khusus ditentukan untuk setiap seri SL yang berkaitan dengan tema payung dimaksudkan sebagai penguatan pengelolaan kolaboratif. Usai pengalaman pertama dalam menggelar SL I di Sumba, rancangan SL menjadi lebih teratur dan dikembangkan berdasarkan konsep pembelajaran orang dewasa dengan siklus belajar: memahami — mengurai — menganalisis menyimpulkan. Secara umum untuk memenuhi konsep pembelajaran tersebut, SL digelar melalui tiga langkah: perencanaan dan persiapan SL, penyelenggaraan SL, dan pengembangan kegiatan pasca-SL.

\section{Langkah Pertama: Perencanaan dan Persiapan SL}

Pengalaman menggelar SL menunjukkan, perencanaan yang matang dan mantap adalah kunci keberhasilan. Rancangan dan persiapan menjadi dasar dalam menyelenggarakan SL. Rencana menggelar SL tidak dengan serta merta dapat 
muncul begitu saja, melainkan berawal dari gagasan-gagasan yang dikembangkan oleh sejumlah pihak.

Perencanaan dan persiapan SL adalah sebuah langkah yang mencakup kegiatankegiatan:

- Merumuskan tema dan tujuan pembelajaran yang hendak dicapai,

- Menyusun kerangka acuan,

- Melakukan refleksi atas seri SL sebelumnya,

- Mempersiapkan tim penyelenggara, tim fasilitator, narasumber, reviewer dan peserta,

- Merancang proses pembelajaran,

- Menentukan lokasi kajian lapangan.

\section{Tema dan Tujuan Pembelajaran}

Meskipun pengetahuan dan pengalaman merupakan bahan utama pembelajaran bersama, tetapi bahan pembelajaran tersebut perlu diatur berdasarkan topik khusus. Idealnya, tema dan tujuan SL ditentukan oleh para peserta dan pemangku kepentingan. Proses penentuannya dapat dilakukan dengan berbagai cara: oleh pembelajar SL seri sebelumnya, dalam sesi 'evaluasi — refleksi — rencana tindak lanjut', melalui angket, ataupun pembahasan terbatas dengan para pihak kunci. Dalam praktiknya, tema muncul pada akhir satu seri SL untuk seri berikutnya atau karena adanya isu hangat yang dibicarakan pada suatu saat tertentu.

Secara ideal pula, pengalaman dari pembelajar menentukan topik khusus SL. Topik pembelajaran yang didasarkan atas masukan peserta akan menjawab kebutuhan di lapangan dan membentuk SL menjadi program pembelajaran bersama yang berkelanjutan.

Dalam praktiknya, hal ini sukar dilakukan secara konsisten karena peserta tidak selalu dapat menarik benang merah pengalamannya. Hasil refleksi menunjukkan, bahan pembelajaran yang ditawarkan cukup bervariasi dan relevan dengan tema payung: kolaborasi atau kemitraan, dan juga dipandang bermakna oleh peserta.

Tema pembelajaran yang dipilih berpengaruh pada komposisi dan jumlah peserta, lokasi belajar, narasumber, dan pendanaan. Pada akhirnya, berpengaruh pula pada pencapaian tujuan pembelajaran dan kejelasan rencana tindak lanjut.

Sebaiknya tema pembelajaran ditentukan secara proaktif, bukan reaktif, atas isu-isu 
yang berkembang. Beberapa hal yang perlu dipertimbangkan dalam menentukan tema adalah:

- Isu strategis terkini yang menjadi perhatian khalayak, misalnya, tata ruang wilayah, bencana alam, atau tata kelola air,

- Isu umum yang terjadi secara khas di sejumlah lokasi sehingga memungkinkan perluasan skala pembelajaran, mengangkat kasus-kasus lokal ke tingkat regional dan nasional, seperti pengelolaan kolaboratif kawasan konservasi,

- Memiliki daya pikat dan mendesak untuk dipelajari, misalnya, kewirausahaan yang ramah lingkungan,

- Berpotensi untuk membangun komunitas pembelajar di tingkat lokal, regional, dan nasional.

\section{Penyusunan Kerangka Acuan}

Setelah melewati tahap penentuan tema dan tujuan pembelajaran, langkah berikutnya adalah membuat landasan konsep dan latar belakang SL. Konsep yang dibuat merupakan hasil curah gagasan dari banyak pihak-peserta seri SL sebelumnya, fasilitator, penyelenggara dan pihak kunci lainnya. Secara praktis, konsep dan latar belakang akan diikhtisarkan dalam kerangka acuan (terms of reference) SL. Kerangka acuan berguna sebagai panduan untuk merancang proses pembelajaran, memilih peserta, dan narasumber yang dibutuhkan sesuai dengan tema SL yang telah dipilih.

Tak hanya itu, seluruh tim penggerak SL_-penyelenggara, fasilitator, reviewerakan memakai landasan konsep sebagai kompas bagi penyelenggaraan kegiatan ini. Landasan konsep harus matang dan jelas untuk memastikan terjaminnya proses pembelajaran. Bagi tim fasilitator, hal itu akan memudahkan dalam merancang dan memandu proses saat berlangsungnya SL; sementara bagi tim penyelenggara, landasan konsep akan melicinkan jalan untuk menjaring narasumber dan peserta yang sesuai dengan topik pembelajaran.

Begitu juga, pihak-pihak kunci lainnya yang akan terlibat dalam SL akan menemukan jalan lapang untuk menyatukan persepsi tentang topik pembelajaran. Penting untuk dicatat, landasan konsep merupakan rujukan yang penting. Bahkan, ketika memilih lokasi pembelajaran, rujukan ini harus disebarkan kepada masyarakat setempat untuk mencapai pemahaman yang sama atas forum SL. 
Kerangka acuan juga memudahkan penjaringan dana dari pihak-pihak lain. Pada SL VI di Taman Nasional Gunung Halimun-Salak (TNGHS), misalnya, tim penggerak juga menggandeng sejumlah pihak-Japan International Cooperation Agency (JICA) dan TNGHS-untuk menyelenggarakan SL yang mengupas Kemitraan dalam Penyusunan Tata Ruang ini. Landasan konsep dan kerangka acuan akan sangat membantu menyatukan pandangan.

\section{Refleksi Seri Shared Learning sebelumnya}

Tak ada satu pun seri SL yang benar-benar sama. Meski secara garis besar mengikuti pola yang sama, setiap seri SL adalah unik. Keunikan ini, rupanya, membuat forum SL menjadi menarik. Perbedaan tidak hanya menyangkut soal tema dan lokasi pembelajaran tetapi juga menyentuh pada proses belajar yang sangat dinamis.

Menelisik kembali forum seri SL sebelumnya sah dilakukan untuk melihat halhal yang perlu diperbaiki, atau dirubah. Mulai dari proses, keterkaitan antarsesi, narasumber, peserta, hingga relevansi lokasi dengan tujuan belajar, mutlak ditelusuri satu per satu. Dengan demikian, bekal pengalaman dan hikmah dari SL sebelumnya akan bermanfaat bagi penyelenggaraan seri SL selanjutnya.

Perbedaan tema setiap seri SL juga mensyaratkan perlunya refleksi terhadap proses pembelajaran yang pernah dilalui. Metode dan teknik pembelajaran dibedah ulang untuk melihat ketepatgunaannya bagi seri SL yang akan digelar. Dari pengalaman, misalnya, terlihat setiap metode dan teknik (Lihat Bab IV) memiliki nilai positifnya. Begitu juga, pengalaman dari sisi penyelenggaraan SL harus dilihat kembali untuk membekali tim penggerak selanjutnya. Bahkan, saat SL V di Yogyakarta, tim penyelenggara, fasilitator, reviewer dan beberapa peserta melakukan refleksi menyeluruh terhadap seri SL yang sudah dilakukan. Forum yang reflektif sangat berguna untuk merenungkan kembali segala dinamika ajang belajar bersama ini.

\section{Bergerak Bersama: Penyelenggara, Fasilitator, Peserta, Reviewer dan Narasumber}

SL merupakan forum pembelajaran bersama dan ajang pertemuan untuk para pihak pembelajar yang berbeda, baik asal daerah, lembaga, pengalaman, latar 
belakang, pendidikan, maupun cara belajar. Agar proses pembelajaran dapat berjalan dengan baik dibutuhkan dukungan tim penyelenggara dan tim fasilitator. Kedua tim ini, meskipun berbeda peran, memiliki titik-tekan yang sama: proses pembelajaran. Keberhasilan kerja sama dan saling mendukung di antara kedua tim ini sangat dibutuhkan. Proses pembelajaran yang dipandu oleh tim fasilitator akan berjalan dengan baik bila mendapat dukungan dari tim penyelenggara; pun, sebaliknya. Pada saat yang sama, reviewer membantu merangkai dan memberi tinjauan terhadap seluruh proses dan substansi SL.

Idealnya, tim fasilitator dan penyelenggara telah dibentuk, sekurang-kurangnya, tiga bulan sebelum pelaksanaan SL. Tim dapat dibentuk atas dasar kerja sama antar-lembaga atau dengan melibatkan individu-individu. Tetapi yang terpenting, tim harus terdiri dari orang-orang yang mampu bekerja sama, memiliki minat dan ketrampilan, didukung sarana kerja yang memadai, dan memiliki kerangka kerja dengan pembagian tugas yang jelas.

\section{Tim Penyelenggara}

Secara khusus, peran dan fungsi tim ini adalah menyusun rencana kegiatan, anggaran, menata pelaksanaan, serta merekam proses dan hasil kegiatan SL. Rencana kerja dan anggaran mencakup kegiatan-kegiatan masa persiapan, pelaksanaan, dan pasca-kegiatan SL. Rencana kerja dan anggaran ini menjadi panduan bagi tim penyelenggara untuk melaksanakan tugasnya dan menjadi acuan bagi lembaga pendanaan. Dalam setiap SL, tata waktu kegiatan merupakan hal yang penting, karena hal itu terkait dengan ketersediaan waktu calon peserta, narasumber, fasilitator, lembaga-lembaga mitra, dan masyarakat di lokasi kajian. Untuk menjalin komunikasi dan koordinasi dengan para pihak itu diperlukan waktu yang cukup.

Tim penyelenggara bertugas merencanakan kegiatan persiapan yang meliputi:

- Pertemuan-pertemuan dengan tim fasilitator,

- Komunikasi dan kunjungan ke berbagai lembaga terkait,

- Kunjungan dan sosialisasi kepada masyarakat di lokasi belajar,

- Penyebaran undangan kepada peserta, pihak kunci dan narasumber.

Di samping itu, tim ini juga harus mempersiapkan tempat pemondokan di lokasi pembelajaran, konsumsi, transportasi, lokasi kajian lapangan, bahan dan alat bantu yang dibutuhkan. Seluruh keperluan yang memperlancar proses belajar 
bersama, entah di ruangan ataupun saat kajian lapangan harus diinventarisasi dan dipenuhi.

Agar seluruh perkembangan terpantau dengan baik, tim ini secara berkelanjutan berkoordinasi dengan tim fasilitator untuk melihat kemajuan yang ada. Selama masa persiapan, tim penyelenggara harus memastikan keterlibatan semua pihaknarasumber, peserta, masyarakat lokal dan pihak kunci lainnya.

Demikian banyaknya aktivitas yang perlu dilakukan sehingga, sekurang-kurangnya, dibutuhkan waktu tiga bulan untuk menyiapkan penyelenggaraan SL. Rencana kegiatan memberi gambaran tentang rencana anggaran atau dana yang dibutuhkan dan sumbernya. Secara umum, jenis-jenis pendanaan yang dibutuhkan meliputi: transportasi, akomodasi, konsumsi, bahan dan alat fasilitasi, honor/balas karya, komunikasi dan dokumentasi. Begitu juga, harus disiapkan komponen biaya yang tak terduga. Hal ini sangat diperlukan, terutama saat kajian lapangan, mengingat banyak perkembangan di luar rencana yang memerlukan dana tak sedikit.

Tim penyelenggara, biasanya, terdiri dari sejumlah orang yang mengisi tugas sebagai:

- Koordinator SL, melakukan koordinasi seluruh kegiatan SL sekaligus menyatukan langkah antara tim fasilitator, penyelenggara dan reviewer,

- Pengelola keuangan, mengatur penggunaan dana selama masa persiapan, pelaksanaan, dan pasca-SL,

- Kesekretariatan, sejak tahap perencanaan, bagian ini sudah bergerak untuk menyebar undangan dan kerangka acuan kepada calon peserta, narasumber, reviewer dan pihak terkait lainnya. Secara umum, koordinasi dan komunikasi semua pihak, internal maupun eksternal, terpusat di kesekretariatan,

- Notulensi, bertugas merekam semua proses dan hasil belajar, terutama catatan diskusi, rekaman suara dan catatan di kertas plano. Notulen juga menerbitkan jurnal harian selama SL berlangsung,

- Perekam visual, terdiri dari dua bentuk rekaman: foto dan video. Perekam visual bertugas merekam seluruh proses belajar dan menyunting hasil rekaman. Hasilnya, foto slide dan video yang ditayangkan secara bergantian selama kegiatan SL,

- Transportasi, mengatur arus transportasi untuk penyelenggara, peserta, narasumber dan fasilitator selama SL. Bagian ini sekaligus bertugas menjadi kurir bagi semua kebutuhan kegiatan SL, 
- Tim pendukung, bertugas memberi kemudahan bagi seluruh pihak yang terlibat. Tim ini menjadi tulang punggung terhadap tugas-tugas apapun yang tidak bisa dipenuhi oleh anggota tim yang lain.

Dalam pelaksanaan SL ada dua jenis dokumentasi yang dibutuhkan, yaitu: visual dan tekstual. Dokumentasi tidak hanya pada peristiwa yang terjadi tetapi juga rekaman materi pembelajaran dalam bentuk arsip elektronik, catatan atau gambar di kertas plano, notulensi dan rekaman yang lainnya. Hasil kedua jenis rekaman itu kemudian disunting dan dipadukan.

Hasilnya, berupa jurnal harian, rekaman film dan foto. Film dan foto sangat penting. Selain untuk review, refleksi harian, serta rekaman proses, juga dapat digunakan untuk memberi semangat para peserta, khususnya bagi mereka yang kurang aktif, sehingga merangsang partisipasi. Jurnal harian sebagai media untuk mengingatkan kembali kepada peserta tentang proses dan materi yang dipelajari, sekaligus sebagai laporan penyelenggaraan SL.

\section{Tim Fasilitator}

Peran dan fungsi utama dari tim fasilitator, di antaranya, adalah mengawal, memandu dan mengembangkan proses pembelajaran untuk mempermudah peserta mencapai tujuan belajar bersamanya. Tim fasilitator dapat dibentuk melalui proses penjaringan, baik formal maupun informal. Seperti juga tim penyelenggara, tim ini harus terdiri dari individu-individu yang memiliki kapasitas memadai, minat yang kuat, mampu bekerja sama, memiliki sikap dasar seorang fasilitator dan ketrampilan fasilitasi.

Fasilitator harus memadai dari segi kualitas dan kuantitas. Jumlah fasilitator sebaiknya disesuaikan dengan jumlah peserta. Perbandingan idealnya, $1: 15$, artinya satu fasilitator maksimal memandu 15 orang peserta. Dengan demikian, diperkirakan jumlah peserta terbanyak yang dapat dikelola maksimal 45 orang. Hal itu juga terkait dengan kemudahan dari sisi logistik dan tata kelola proses pembelajaran.

Fasilitator perlu memastikan partisipasi penuh dengan membatasi pihak yang mendominasi proses dan memberdayakan pihak yang tersudut. Tim ini harus lebih memikirkan bagaimana mendudukkan semua peserta berperan setara dan seimbang. 
Tim fasilitator harus memiliki waktu yang cukup untuk melakukan persiapanpersiapan agar tujuan SL dapat tercapai. Persiapan tersebut meliputi:

- Merumuskan (kembali) tema dan tujuan pembelajaran,

- Merancang proses pembelajaran,

- Menentukan metode dan teknik pembelajaran,

- Menyusun rencana sesi dan pembagian tugas.

\section{Peserta}

Para peserta SL harus dapat meraih tujuan pembelajaran. Keikutsertaan dan partisipasi aktif setiap peserta menentukan kelancaran dan keberhasilan proses belajar. Dengan demikian, mereka harus diseleksi dan dipersiapkan dengan baik sebelum SL dilaksanakan. Hal ini berguna untuk menentukan atau menyaring substansi yang relevan dari para peserta, agar selama SL berlangsung tidak terjadi 'banjir' informasi. Keterbukaan ada batasnya, peserta harus dipilih: memiliki pengalaman yang sesuai dengan pokok bahasan dan bersedia memenuhi kewajiban tertentu. Persiapan bagi peserta juga akan menjamin pengalamannya menjadi pelajaran yang menarik dan dilaksanakannya kegiatan lanjutan pasca-SL.

Untuk mendorong proses multipihak perlu diusahakan kehadiran peserta yang beragam, terutama wakil dari pihak-pihak yang berkaitan dengan tema pembelajaran. Sebagai panduan praktis, secara umum, peserta yang diundang harus menunjukkan keterwakilan unsur masyarakat, pemerintah, swasta, LSM serta keseimbangan jender-peran sosial berdasarkan jenis kelamin.

Hal itu memang tidak mudah. Seringkali unsur pemerintah, apalagi pihak swasta, kurang terwakili. Keseimbangan jender juga belum menjadi perhatian khusus. Selama ini jumlah kehadiran kaum perempuan hanya 10 persen-pada SL V, Kemitraan dalam Pengelolaan Sumberdaya Air, seluruh kaum perempuan berasal dari masyarakat lokal. Keadaan di Indonesia, secara umum, cukup menyulitkan menjaring peserta yang dapat meninggalkan keluarga dan tugasnya selama 10 hari; tetapi, sangat disadari perlunya usaha khusus untuk lebih mendorong keterwakilan perempuan dalam forum pembelajaran.

\section{Tim Reviewer}

Tugas memantau proses pembelajaran dan memberikan tinjauan terhadap proses yang telah dilalui berada di pundak reviewer atau pengamat. Selain itu, tim 
pengamat juga harus memberikan pandangannya tentang substansi yang telah dibahas. Hal itu diperlukan untuk membantu pembelajar berefleksi terhadap proses pembelajaran bersama.

Tim ini juga harus mampu merangkai beragam substansi pokok bahasan yang telah dipaparkan oleh narasumber ataupun peserta untuk memudahkan proses belajar selanjutnya. Hasil rangkaian itu menjadi bekal bagi pembelajar dalam mencapai tujuan belajar. Hasil pengamatan, lazimnya, disampaikan pada saat acara harian dimulai. Di samping mengingatkan kembali proses sebelumnya, peserta juga bisa mempersiapkan diri untuk mengikuti proses selanjutnya.

Untuk membuka partisipasi penuh, SL juga memberi kesempatan kepada pembelajar untuk memberikan review sesuai pandangannya. Hasil pengamatan pembelajar, yang terlibat langsung dalam proses pembelajaran, akan melengkapi hasil tinjauan para reviewer.

\section{Narasumber}

Kendati seluruh peserta SL adalah narasumber bagi pengalaman dan pengetahuannya, tetapi kehadiran narasumber dengan keahlian yang spesifik tetap dibutuhkan. Forum SL I, di Sumba, yang membahas tentang monitoring dan evaluasi kolaboratif, misalnya, memberi catatan menarik tentang nilai penting kehadiran narasumber. Saat itu, para peserta belum berhasil menjelaskan hubungan antara adat dengan agama. Lantas, muncul sengketa antara tokoh agama dengan tokoh adat. Tokoh agama melihat nilai-nilai adat tidak perlu dihidupkan kembali karena bertentangan dengan agama, sehingga kelembagaan adat harus diambilalih oleh otoritas agama.

Hikmah dari peristiwa itu adalah fasilitator harus mengatur substansi dan membangun kesepakatan dengan narasumber. Pengetahuan narasumber dapat memberikan pencerahan kepada pembelajar, misalnya, pencerahan tentang keterkaitan hulu-hilir daerah aliran sungai (DAS), pentingnya integritas ekosistem, kebijakan dan sebagainya.

Untuk hal-hal tertentu yang bersifat spesifik, seperti kebijakan, teknik menyusun rencana usaha, dan pengelolaan konflik, dibutuhkan seorang narasumber untuk menjabarkannya. Narasumber juga bisa ditempatkan untuk memperoleh dukungan pemerintah, kebutuhan diplomasi dan advokasi. Narasumber yang bisa memenuhi 
kebutuhan diplomasi tetap dibutuhkan karena kehadirannya merupakan peluang langka untuk dapat berdialog dengan masyarakat.

Usaha mencari pembicara yang tepat, sambil tetap menjaga keseimbangan antara diplomasi dan kebutuhan peserta, merupakan tantangan khusus. Hal itu bisa dicapai dengan memberi penjelasan awal (briefing) kepada narasumber tentang para pembelajar, latar belakang dan harapan mereka, sementara pada saat yang sama, peserta diberi informasi mengenai sang pembicara. Dalam banyak kasus, hal itu juga bermanfaat untuk membatasi peserta untuk tidak menanyakan sesuatu di luar bidang narasumber bersangkutan. Di sini, kerangka acuan bagi pembicara harus lebih jelas dan terinci.

Perlu juga dipikirkan dalam menghadapi kenyataan bahwa narasumber-terutama dari pejabat pemerintahan, sukar ditemui dan sulit memenuhi permintaan menjadi pembicara; pun, perlu diperhatikan, tidak semua narasumber benarbenar menguasai bidangnya. Lantaran itu pula, narasumber untuk keperluan diplomasi harus diperlakukan berbeda dari narasumber yang mengisi kebutuhan substansial.

\section{Merancang Proses Pembelajaran}

Rancangan proses pembelajaran dalam SL harus mampu menjawab pertanyaanpertanyaan berikut ini:

- Apa tujuan pembelajaran bersama yang akan dicapai?

- Bagaimana belajar bersama dapat berlangsung?

- Apa yang akan dipelajari dan mengapa?

- Bagaimana menemukan sesuatu yang dibutuhkan untuk belajar?

- Siapa yang akan melakukan apa dan kapan?

Pembelajaran selama SL adalah sebuah proses pembelajaran bagi orang dewasa yang mengedepankan kemandirian peserta dalam mencari jalan keluar atas persoalannya. SL menggabungkan dua cara belajar, yaitu: pengalaman dan pengetahuan baru. Dengan demikian, ajang SL meramu proses pembelajaran secara dinamis, adaptif, tidak mekanistik dan rutin.

Dalam tujuh kali menggelar forum ini, disadari tidak ada standar baku proses belajar dalam SL. Tetapi secara umum dapat ditunjukkan beberapa komponen tahap pembelajaran, yang mencakup: orientasi, berbagi pengalaman, kajian 
lapangan, refleksi serta rencana tindak lanjut. Komponen ini melapangkan jalan bagi perancangan proses belajar. Meski begitu, tetap disadari bahwa ketika proses belajar berlangsung, tahap demi tahap harus dipantau untuk merefleksikan proses yang dilalui.

Beberapa hal yang mendasar untuk menjadi pertimbangan dalam merancang proses adalah:

- Mengacu pada siklus pembelajaran orang dewasa: mengalami-mengurai — menganalisis - menyimpulkan untuk mengembangkan tindakan baru (perubahan). Metode pembelajaran yang digunakan dalam setiap tahapan dalam SL harus membuka kesempatan bagi setiap peserta melalui siklus tersebut.

- Berpedoman pada tujuan yang hendak dicapai. Apakah rancangan yang disusun memungkinkan peserta untuk mencapai tujuan pembelajaran? Proses yang dikembangkan untuk memudahkan, memberi jalan keluar serta mendorong pembelajar mencapai tujuan strategis untuk perubahan sosial, dan tujuan praktis dalam meningkatkan kapasitasnya.

- Partisipasi peserta. Keberagaman peserta, baik latar belakang, asal daerah, pengalaman, maupun gaya belajar menjadi keunikan dan kekuatan SL. Dibutuhkan sebuah proses dan metode belajar yang dapat diterima dan mendorong mereka untuk berpartisipasi.

- Daya lenturyang tinggi. Kelenturan proses memungkinkan bagi perubahan dan penyesuaian sepanjang hal itu tidak menyimpang dari pencapaian tujuan. Proses yang lentur juga membuka pintu dalam merespon agendaagenda yang tak terduga. Hal ini berlaku ketika proses belajar berlangsung di lokasi kajian lapangan; banyak hal bisa terjadi di luar dugaan yang mensyaratkan kelenturan proses belajar.

Hampir setiap langkah dalam seluruh tahap pembelajaran menjadi alat bantu utama dalam mendorong proses pembelajaran. Metode dan teknik yang dipilih atau diciptakan untuk mempermudah peserta dalam mencapai tujuan pembelajaran.

\section{Menentukan Lokasi Kajian Lapangan}

Sebelum ditentukan, tim penggerak SL-fasilitator dan penyelenggara-harus mempunyai beberapa calon lokasi pembelajaran sesuai dengan topik SL. Setelah menampung informasi dari berbagai pihak dan melakukan kajian, baru bisa ditentukan lokasi yang pas dengan topik pembelajaran. 
Selanjutnya, untuk memastikan kelayakan lokasi yang dipilih, dilakukan survei awal ke lokasi tersebut. Sepanjang survei awal ini, secara umum, beberapa informasi harus sudah diperoleh, di antaranya:

- Kesesuaian lokasi dengan topik pembelajaran. Selama kunjungan awal, setidaknya, telah terjaring informasi tentang peluang adanya kasus yang bisa dipelajari; misalnya, kasus lokal yang bisa dikaji oleh pembelajar SL. Dalam SL III dengan tema Manajemen Konflik dalam Pengelolaan Sumberdaya Alam, Tangkahan, Sumatera Utara, misalnya, dipilih berdasarkan pertimbangan letak Tangkahan yang berada di sekitar Taman Nasional Gunung Leuser. Tangkahan juga memendam cerita menarik dalam penghentian pembalakan liar (illegal logging) dan pengembangan ekowisata yang dikelola masyarakat. Hasil survei awal, secara umum, menggambarkan adanya kecenderungan perubahan minat masyarakat Tangkahan dari penebang kayu ilegal menjadi penyedia jasa lingkungan dari aktivitas pariwisata ekologis. Kisah kian menarik dengan adanya sengketa antara masyarakat yang pro dan kontra, ataupun yang abstain, terhadap perubahan itu. Slogan 'merakyatkan hutan negara' menjadi salah satu temuan yang menarik. Sebaiknya, survei awal diikuti survei berikutnya untuk memastikan bahwa kesan pertama memang benar adanya.

- Keunikan kasus yang terjadi di lokasi yang akan dikunjungi. Tomohon memberikan pengalaman menarik dalam pengembangan hasil hutan bukan kayu (HHBK) pada saat SL IV tentang "Kemitraan dalam Pengelolaan Hasil Hutan Bukan Kayu." Pengalaman masyarakat Tomohon sangat bermanfaat untuk memperluas pengetahuan peserta, begitu juga sebaliknya.

- Keterjangkauan lokasi. Aspek ini juga berpengaruh besar bagi kelancaran penyelenggaraan SL. Tempat belajar yang gampang dijangkau akan memudahkan pekerjaan yang lain, terutama transportasi dan akomodasi. Adanya fasilitas pendukung lain juga perlu diperhitungkan untuk melihat berbagai alternatif bagi persoalan yang tak terduga. Keberadaan puskesmas terdekat juga harus diketahui untuk mengantisipasi gangguan kesehatan peserta maupun tim penggerak SL.

- Dukungan dari lembaga dan masyarakat setempat. Sebagai arena belajar bersama, SL juga harus membuka ruang bagi masyarakat setempat untuk berpartisipasi dalam proses belajar. Lagi-lagi, ini berkaitan dengan watak SL yang berbasis pembelajaran bagi orang dewasa melalui interaksi sosial. Keikutsertaan masyarakat lokal merupakan bagian tak terpisahkan dalam proses pembelajaran, mereka turut memberi andil terjadinya pertukaran pengalaman dan pengetahuan. Kajian lapangan akan gagal sepenuhnya 
tanpa adanya jaminan dukungan dari lembaga dan masyarakat lokal. Hampir separuh proses belajar SL terjadi di lapangan sehingga pengalaman dan pengetahuan yang kontekstual untuk menjawab kebutuhan peserta akan ditentukan dalam kajian desa ini.

\section{Langkah Kedua: Penyelenggaraan dan Fasilitasi Shared Learning}

Setelah memastikan berbagai hal pada langkah perencanaan dan persiapan, SL memasuki langkah kedua, penyelenggaraan dan fasilitasi. Sebagai media belajar bersama yang terpadu, pada saat penyelenggaraan SL, seluruh tim penggerak bekerja sesuai peran dan fungsinya.

Agar proses belajar menggelinding tanpa halangan, secara terus-menerus tim penggerak, narasumber, reviewer, pembelajar dan pihak lain yang terlibat harus melakukan koordinasi dan komunikasi. Seluruh komponen itu bekerja secara organik untuk mencapai tujuan pembelajaran yang hendak dicapai. Masingmasing organ SL berdetak secara serempak, saling memudahkan dan mencari solusi setiap ada perkembangan tak terduga. Daya lentur sangat dibutuhkan agar respon terhadap perubahan sepanjang SL menjadi bekal positif bagi pembelajaran bersama.

Pada langkah kedua ini sangat diperlukan kesabaran untuk terus memantau proses dan dinamika yang terjadi. Tim fasilitator dan penyelenggara secara simultan melakukan refleksi, tahap demi tahap, serta bergandengan tangan demi kelancaran proses SL.

Berbekal pengalaman tujuh putaran SL, saat pelaksanaan kegiatan ini, tim penyelenggara akan menghadapi tiga tahap kritis, yaitu:

- Hari pertama SL merupakan saat yang sangat sibuk. Seluruh tim penyelenggara nyaris terserap pada tiga aktivitas: menjamin kelancaran transportasi peserta, pendaftaran ulang peserta, penataan ruang belajar dan pembagian penginapan bagi peserta.

- Saat mulai kajian lapangan, tim penyelenggara akan menghadapi dua fokus kegiatan: pemberangkatan dari tempat belajar di ruangan dan penyambutan di lokasi kajian lapangan. Saat berangkat harus dipastikan kelancaran transportasi sementara penyambutan di lapangan menyangkut 
persiapan penginapan, konsumsi, kehadiran masyarakat dan lembaga setempat.

- Hari terakhir pelaksanaan SL, penyelenggara harus mempersiapkan dengan baik kepulangan pembelajar, fasilitator, dan reviewer.

Sepanjang tiga masa kritis tersebut, seluruh tim penyelenggara harus melakukan koordinasi dengan seluruh tim penggerak SL. Informasi yang lengkap harus diberikan kepada peserta untuk menghindari kendala yang tidak dikehendaki.

Secara umum, berikut ini beberapa forum yang akan dilalui oleh para peserta selama SL dilaksanakan. Seluruh forum yang digelar, sekali lagi, untuk melapangkan jalan bagi proses belajar bersama dengan tetap berpegangan pada prinsip-prinsip SL.

\section{Pembukaan dan Orientasi}

Menghadirkan pejabat terkait dalam acara pembukaan menjadi sebuah kebutuhan bila SL dirancang sebagai arena advokasi, diplomasi dan promosi, terutama, kepada pihak pemerintah pusat dan daerah. Meskipun proses advokasi, diplomasi dan promosi dapat terjadi di luar sesi pembukaan resmi, sedapat mungkin diusahakan agar pejabat yang hadir dapat mengikuti diskusi pada sesi tertentuberbagi pengalaman, seminar, atau klinik. Hal tersebut juga bisa ditempuh dengan melibatkan para pejabat sebagai narasumber dan mengikuti kegiatan SL secara keseluruhan.

Setelah pembukaan, pembelajar SL memasuki tahap orientasi yang bertujuan untuk:

- Menciptakan suasana yang mendukung bagi proses pembelajaran,

- Mendorong peserta saling mengenal dan membuka pikiran,

- Membantu peserta ke arah cara belajar yang efektif bagi perubahan,

- Menumbuhkan keberanian untuk melihat diri, memberi dan menerima umpan balik.

Materi-materi yang wajib dibahas dalam orientasi meliputi:

- Landasan konsep dan tujuan SL. Seluruh peserta dan pihak kunci yang terlibat harus mengetahui landasan konsep dan tujuan SL yang sedang berlangsung. Hal ini bertujuan untuk memberi satu panduan yang akan ditaati oleh semua peserta. Selain itu, juga untuk menyamakan persepsi agar selama proses belajar para peserta bisa memaparkan seluruh pengalamannya secara terarah. 
- Proses dan metode belajar. Masih berhubungan dengan konsep dan tujuan adalah proses dan metode belajar. Materi ini harus dipaparkan untuk memberi gambaran tahap-tahap belajar bersama kepada peserta. Hal ini juga dimaksudkan agar para peserta mempersiapkan diri untuk melakoni seluruh proses SL, baik ketika berbagi pengalaman, merancang kajian lapangan maupun saat melakukan refleksi. Materi ini juga melengkapi pedoman belajar bersama para peserta.

- Peta harapan dan kekhawatiran peserta. Materi ini berguna untuk mengetahui persepsi awal para peserta terhadap tema yang dibahas dalam SL. Kebutuhan peserta akan topik SL bisa terlihat pada peta harapan sementara peta kekhawatiran membantu tim penggerak SL menciptakan suasana belajar yang nyaman untuk menghilangkan rasa khawatir para peserta. Hal ini penting, agar selama proses belajar berlangsung para peserta merasa setara dan memiliki rasa bebas untuk berbagi pengetahuan.

- Jaring-jaring kapasitas peserta. Secara umum, materi ini berguna untuk mendapatkan informasi awal tentang pengetahuan dan pengalaman yang dimiliki para peserta. Pada tahap pembelajaran selanjutnya, informasi awal ini juga penting untuk menentukan metode dan teknik belajar.

- Norma belajar. Untuk membentuk kenyamanan, salah satunya, dengan adanya norma belajar bersama. Seluruh peserta, fasilitator dan penyelenggara akan berpegangan pada norma ini. Meski SL memberi kebebasan bagi para pesertanya, untuk menjamin kelancaran proses, tetap saja diperlukan norma belajar ini. Dengan demikian, diharapkan, tercipta kesetaraan bagi semua pihak.

Tahap orientasi merupakan tahap awal yang penting untuk membentuk suasana belajar yang nyaman bagi semua peserta. Tahap ini sangat menentukan untuk melewati sesi-sesi pembelajaran di ajang SL tanpa hambatan. Tim fasilitator dan penyelenggara SL harus menajamkan kepekaan mulai dari sesi ini untuk memperlancar proses-proses selanjutnya.

\section{Berbagi Pengalaman}

Inti SL adalah berbagi pengalaman yang memberi ruang seluas-luasnya bagi peserta untuk saling tukar pengetahuan. Pengalaman peserta menjadi bahan utama pada tahap ini. Setiap peserta menyampaikan seluruh pengalaman dan pengetahuannya mengenai tema yang dibahas sepanjang SL. 
Kebebasan media yang digunakan untuk berbagi pengalaman diberikan kepada para peserta. Biasanya, tim fasilitator dan penyelenggara telah memperoleh informasi tentang media yang akan digunakan oleh peserta. Hal ini bermanfaat dalam menentukan metode presentasi yang tepat.

Meski begitu, agar presentasi lebih terarah, peserta diharapkan mengikuti struktur proses melalui pertanyaan-pertanyaan kunci. Selama SL II, bertema Pengelolaan Kolaboratif untuk Kawasan Konservasi, misalnya, dimunculkan pertanyaanpertanyaan kunci: mengapa diperlukan kolaborasi dalam pengelolaan kawasan konservasi?, Apa manfaat dan kerugian yang diperoleh dengan melakukan kolaborasi?, Bagaimana strategi pengembangannya?, Upaya apa yang dilakukan untuk menjalankan kolaborasi?, Bagaimana peran masyarakat lokal dalam kolaborasi?, Apa tantangan yang dihadapi?, Pelajaran apa yang bisa dipetik?

Pertanyaan kunci membantu para pihak yang belajar untuk memaparkan semua gagasan, pengalaman dan pengetahuan secara terarah. Tahap berbagi pengalaman ini sangat rentan terhadap penyimpangan substansi dan arah pembelajaran mengingat begitu meluapnya pengetahuan para peserta yang beragam. Meski pada sesi orientasi telah dijabarkan beberapa materi yang menyangkut konsep, tujuan, proses dan metode pembelajaran SL, tim penggerak harus tetap peka terhadap dinamika yang terjadi saat berbagi pengalaman.

Forum berbagi pengalaman dilakukan dengan beragam metode dan teknik pemaparan. Selain mencegah munculnya rasa jenuh, variasi metode dan teknik juga ditujukan untuk memunculkan pengalaman para peserta. Pada saat yang sama, diharapkan pula terbentuk suasana belajar yang memungkinkan semua pihak bisa berbagi pengalaman secara sejajar dan setara. Ketika SL V, Kemitraan dalam Pengelolaan Sumberdaya Air di Yogyakarta, forum berbagi pengalaman terdiri dari: seminar, klinik, dan diskusi kelompok terarah (focused group discussion/FGD), agar pertukaran pengetahuan dan pengalaman berjalan lancar dan terarah.

Untuk melapangkan proses belajar, peserta bisa dipecah dalam beberapa kelompok, kemudian saling bertukar pengetahuan di masing-masing kelompok. Pengelompokan ini didasarkan subtema yang sudah disepakati bersama oleh peserta. Diskusi kelompok dilakukan secara serempak, lalu dilaksanakan diskusi pleno untuk menyatukan pengalaman dan pengetahuan yang telah diperoleh oleh setiap kelompok. 
Pada dasarnya, berbagi pengalaman bertujuan untuk:

- Memberi kesempatan yang setara kepada semua peserta untuk menyampaikan pengalamannya,

- Melakukan analisis dan sintesis atas pengalaman bersama yang dimiliki, meliputi pengetahuan, pemahaman, keterampilan, gagasan, sikap (baru) bersama,

- Menentukan topik/isu yang perlu dibahas lebih lanjut,

- Memetik hikmah dan pelajaran dari kekayaan pengalaman serta pengetahuan yang ada.

Babak berbagi pengalaman akan berlangsung dengan baik jika seluruh tim penggerak SL bekerja secara kompak. Tim penyelenggara menyiapkan jadwal harian untuk memudahkan peserta melihat secara umum proses yang akan dijalani. Tim ini juga bertanggung jawab dalam menyiapkan seluruh materi berbagi pengalaman beserta alat bantunya.

Penentuan metode dan teknik berbagi pengalaman menjadi tugas tim fasilitator. Tim ini secara terus-menerus memantau konsistensi arah pembelajaran dalam mencapai tujuan belajar. Dinamika dan perkembangan proses berbagi pengalaman, baik suasana belajar, tingkat partisipasi peserta, perbedaan persepsi, maupun cara fasilitasi, harus ditelisik secara mendalam oleh tim fasilitator.

Ketika membahas kewirausahaan sumberdaya alam yang ramah lingkungan pada SL ketujuh, di Taman Nasional Gede Pangrango, misalnya, dijumpai beberapa peserta yang dominan dan resisten — hal seperti ini lazim terjadi pada setiap seri SL. Celah yang mengganggu untuk menciptakan suasana belajar yang nyaman seperti itu, harus segera diatasi oleh tim penggerak SL, terutama fasilitator. Di samping cukup mengganggu kelancaran proses belajar, keadaan itu juga tidak menguntungkan peserta yang cenderung pasif.

\section{Kajian Lapangan}

Kajian lapangan merupakan metode belajar bersama yang paling disukai, baik oleh peserta maupun masyarakat setempat. Bagi masyarakat lokal, di mana kajian desa dilakukan, SL memberi kesempatan kepada mereka untuk melihat kehidupan desanya dari 'kacamata' yang sama sekali lain. Untuk peserta SL, kajian lapangan membuka ruang untuk memperoleh pengetahuan secara kontekstual. 
Pada media belajar inilah terjadi titik temu antara teori dan praktik atau, sebaliknya, bertemunya praktik dengan teori. Kebaruan pengetahuan bagi masyarakat setempat dan peserta terjadi ketika proses pembelajaran berlangsung secara interaktif. Kajian desa sangat ampuh untuk memperluas skala pembelajaran bagi kedua belah pihak; proses pembelajaran berlangsung tidak sebatas lingkup peserta SL tapi meluas dan menular kepada penduduk lokal.

Dengan melakukan kajian lapangan, seluruh peserta dapat berinteraksi dengan penduduk lokal. Segala pengalaman peserta sangat bermanfaat, tidak hanya saat kajian lapangan, tetapi juga ketika bertukar pengetahuan dengan masyarakat. Peluang ini sangat terbuka, mengingat para peserta menginap di kediaman penduduk dan merasakan langsung gerak kehidupannya.

Untuk menghargai keragaman kasus yang mungkin bisa dikaji, SL sedapat mungkin melakukan kajian lapangan di dua tempat yang berbeda. Selain untuk memperkaya bahan kajian, hal itu juga penting untuk memberi kesempatan kepada para peserta untuk mendapatkan pengetahuan dengan konteks yang berbeda-beda. Lokasi yang berbeda ini, bisa saja berada pada wilayah administrasi yang berbeda, atau sebaliknya, masih berada di wilayah administrasi yang sama.

Kajian lapangan SL II diadakan di lokasi yang secara administratif berbeda, yaitu: di sekitar Taman Wisata Alam Gunung Pancar, Kabupaten Bogor, dan Hutan Lindung Gunung Simpang, Kabupaten Cianjur. Sebaliknya, pada SL VI, kajian lapangan dilakukan di wilayah administrasi yang sama, Kabupaten Sukabumi. Hanya saja, kemudian peserta dibagi dalam dua lokasi berbeda, yaitu Kampung Sukagalih dan Kampung Cipeuteuy, Desa Cipeuteuy, di seputar Taman Nasional Gunung Halimun-Salak.

Pada tahap kajian desa ini, seluruh proses belajar dilakukan sendiri oleh para peserta, mulai dari rancangan kajian desa, fasilitasi, teknik pencarian informasi hingga pembagian tim kerja. Pada babak kajian lapangan inilah, para peserta benar-benar memiliki keleluasaan untuk belajar melalui interaksi sosial yang mereka tentukan sendiri. Nilai lebih kajian lapangan terletak pada kemandirian peserta untuk mencari jalan keluar bagi masalah yang dihadapinya.

Tim fasilitator dan reviewer bertugas memantau proses kajian lapangan dan memberi kepercayaan sepenuhnya kepada kemampuan peserta dalam melakukan pembelajaran bersama di lapangan. Masukan dan saran hanya diberikan seperlunya, tanpa bermaksud untuk menggiring peserta ke arah pembelajaran 
tertentu. Kesabaran menjadi salah satu modal yang harus dimiliki oleh fasilitator pada tahap kajian lapangan ini.

\section{Evaluasi, Refleksi, dan Rencana Tindak Lanjut}

Semua tahap proses pembelajaran berwatak dinamis sehingga sangat dirasakan perlu untuk melakukan evaluasi dan refleksi. Para peserta, bersama dengan tim fasilitator, reviewer dan penyelenggara, melakukan evaluasi dan refleksi secara menyeluruh proses belajar. Tahap ini terfokus pada proses dan pencapaian tujuan pembelajaran bersama sekaligus memberi kesempatan bagi peserta untuk:

- Melakukan penilaian tingkat keberhasilan dan kegagalan pembelajaran,

- Memberi umpan balik untuk perbaikan proses pembelajaran berikutnya,

- Merencanakan tindakan/agenda selanjutnya (pribadi, kelompok, institusi).

Evaluasi terhadap pelaksanaan SL dilakukan sepenuhnya oleh para peserta. Seluruh lini penyelenggaraan-mulai dari akomodasi, transportasi, proses belajar, fasilitator hingga penyelenggara, dinilai untuk mengetahui pandangan para peserta. Dari hasil evaluasi akan diketahui tingkat keberhasilan atau kekurangan semua lini yang terlibat dan bisa dijadikan bekal bagi pelaksanaan SL selanjutnya.

Proses pembelajaran, secara khusus, akan direfleksikan bersama-sama. Peserta melakukan refleksi untuk memahami dan mengingat kembali seluruh tahap pembelajaran, baik proses maupun substansinya. Refleksi merupakan kegiatan yang lazim selama kegiatan SL. Dengan demikian, peserta akan memberikan umpan balik, untuk tim penggerak SL maupun dirinya sendiri, yang mengarah pada perbaikan. Mengetahui hasil pemikiran reflektif para peserta tentang proses pembelajaran sangat diperlukan, mengingat mereka mengalami langsung di dalamnya.

Refleksi juga dilakukan oleh para reviewer yang secara simultan mengikuti dan mengamati proses-proses belajar bersama. Hasil refleksi pengamat ini bermanfaat untuk para peserta dalam merangkai berbagai substansi dan proses yang dialaminya. Baik refleksi dari peserta maupun reviewer, sama-sama bernilai positif bagi pencapaian tujuan belajar.

Dengan mengikuti seluruh rangkaian proses pembelajaran bersama, peserta bisa membuat rencana tindak lanjut, entah bagi dirinya sendiri maupun kelompoknya, 
usai kegiatan SL. Mengetahui dan memahami rencana tindak lanjut peserta ini berfaedah untuk memicu pembelajaran bersama di tempat asal peserta.

\section{Langkah Ketiga: Menata Kegiatan Pasca-Shared Learning}

\section{Menerbitkan Pembelajaran Bersama}

Pada umumnya semangat untuk mengikuti SL cukup tinggi. Hanya saja, usai kegiatan SL, apakah forum ini mampu membuat orang belajar bersama di daerahnya masih sukar dilacak. Ada sebagian peserta, yang tampaknya tidak belajar sungguh-sungguh, tetapi ada pula yang 'kesurupan' dan bersemangat melanjutkan pembelajaran bersama. Meskipun demikian, perlu perhatian khusus untuk memicu pembelajaran dalam hal mempertanyakan, dipertanyakan dan merumuskan pertanyaan tentang pengelolaan sumberdaya hutan. Ini penting untuk membentuk kesadaran kritis secara kolektif.

Buah SL seringkali memang baru tampak sesudah jangka waktu tertentu. Proses belajar bersama secara mandiri jarang terlihat secara nyata pada saat SL berlangsung, dan hasilnya, mungkin baru muncul sesudah peserta pulang. Ada pula sejumlah peserta yang benar-benar terlihat belajar ketika telah mengikuti kegiatan ini selama dua hingga tiga kali. Kehadiran yang rutin dalam forum SL memungkinkan peserta berhubungan lebih intensif pasca-kegiatan.

Maka, idealnya, forum ini diikuti oleh survei pasca-SL dan/atau pemantauan berkala. Dalam rencana awal SL, memang ada niat baik untuk melakukan pemantauan belajar bersama yang dilakukan peserta di daerah asalnya. Karena waktu dan biaya, sejauh ini pengamatan masih terjadi secara acak ketika bertemu alumni SL. Disamping itu, SL masih berpeluang untuk lebih menyentuh aspek pengetahuan daripada ketrampilan dan sikap.

\section{Pembentukan Jaringan}

Salah satu aspek paling menonjol dari kegiatan SL adalah terbentuknya jaringan. Pada awalnya, sudah dipikirkan bahwa jaringan antar-peserta perlu diperkuat 
melalui komunikasi pasca-SL. Hanya saja, sampai saat ini belum ada mekanisme komunikasi yang teratur dan efektif.

Karena itu, masih sangat samar untuk melihat jaringan yang terbentuk. Namun, forum SL yang mempertemukan banyak pihak untuk saling bertukar pengalaman telah terbukti menebar benih berjaringan. Wakil masyarakat dari Gunung Simpang, Cianjur, Jawa Barat, misalnya, berjumpa dengan orang dari Danau Sentarum, Kalimantan Barat, yang keduanya mempunyai ketrampilan khusus. Warga Simpang memperoleh ketrampilan memelihara lebah hutan; sebaliknya, masyarakat Sentarum belajar tentang pembangkit listrik skala kecil.

Ketika warga Barukusumah, Desa Kebonpeuteuy, Cianjur, tempat diadakannya SL VII, tentang Kewirausahaan Sumberdaya Alam yang Ramah Lingkungan, membutuhkan ketrampilan membuat pupuk organik, peserta dari Berastagi, Karo, Sumatera Utara, berkesempatan menularkan pengalaman dan pengetahuannya tentang pertanian organik.

Rupanya, jaringan pertukaran pengetahuan seperti itu menjadi dampak paling berharga dari forum SL ini. Tentu saja, benih berjaringan ini harus dijaga dan dikembangkan melalui media apapun yang memungkinkan. Dengan berkembangnya jaringan telepon seluler dan melihat banyaknya peserta-dari daerah terpencil sekalipun-yang menggunakan teknologi ini maka perlu dipikirkan untuk memanfaatkannya sebagai cara praktis berjaringan.

\section{Pengembangan Kemitraan}

Keberhasilan media belajar SL adalah buah manis adanya kemitraan, baik pihak internal maupun eksternal CIFOR. Kemitraan utama yang terbentuk adalah antara CIFOR dengan PILI. Sejumlah seri SL juga hasil dukungan dari pihak luar, seperti pemerintah daerah setempat, MFP-DfID, JICA, WWF, taman nasional dan Departemen Kehutanan.

Dari pihak CIFOR, SL juga merupakan peluang untuk mengaitkan berbagai proyek internal, seperti, proyek ACM-Jambi, ACM-Danau Sentarum, Kalimantan Barat, ACM-Malinau, Kalimantan Timur, proyek resolusi konflik di Papua dan program livelihood. Sebelumnya, proyek-proyek ini tersebar dan kurang berhubungan. 
Untuk memudahkan para pembelajar meraih tujuannya, fasilitasi proses belajar bersama harus bersifat adaptif dan berdasarkan prinsip-prinsip utama $S \mathcal{L}$.

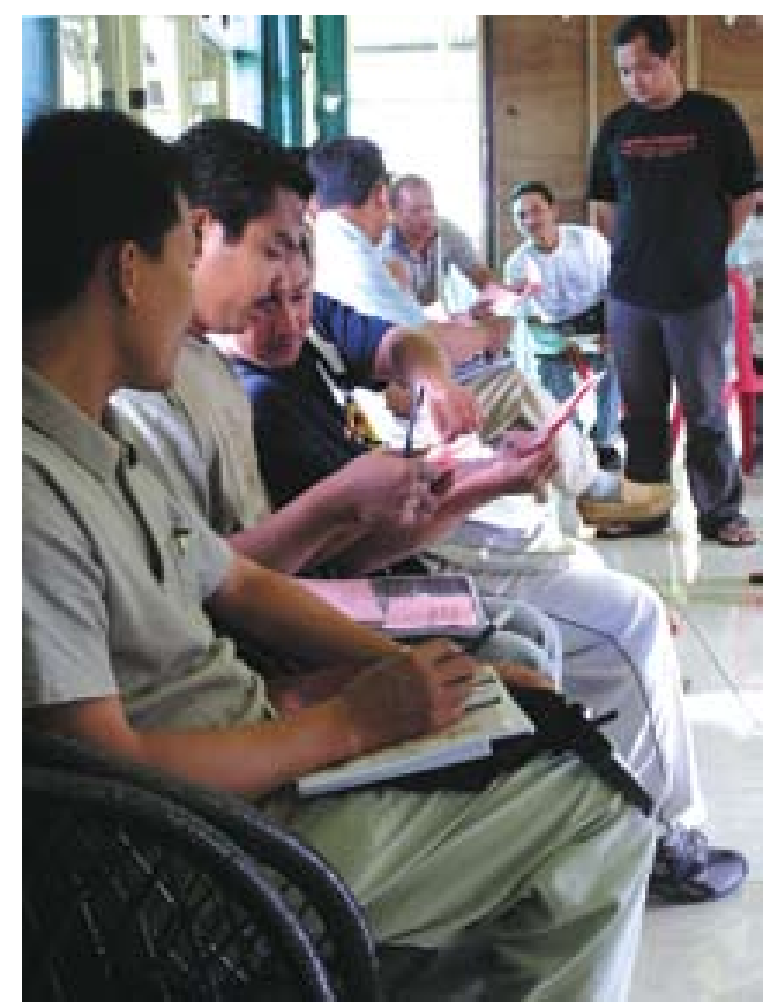




\section{BAB III}

\section{Fasilitasi dan Fasilitator: Menebar Proses, Menuai Perubahan}

Kunci keberhasilan pembelajaran bersama, pertama-tama, terletak pada fasilitasi. Tetapi, jika fasilitasi diterapkan tanpa didasari oleh pengetahuan, sikap, dan ketrampilan yang memadai justru akan mengikis makna sejati dari fasilitasi, dan membuat proses belajar bersama berjalan lamban.

Selama pembelajaran bersama dalam forum Shared Learning (SL), fasilitasi dikembangkan sejalan dengan kebutuhan dan pertimbangan strategis. Bagian ini akan menguraikan secara singkat tentang apa dan mengapa fasilitasi, nilai-nilai dasar fasilitasi, fasilitator dan perannya, dan ketrampilan yang perlu dimiliki oleh seorang fasilitator.

\section{Apa dan Mengapa Fasilitasi}

Kata fasilitasi berasal dari bahasa Prancis: facile, yang artinya, mudah atau membuat 'sesuatu' menjadi mudah. 'Sesuatu' dalam kalimat itu dapat diartikan: memahami 
hal yang rumit, kerja sama, dialog multipihak, membuat kesimpulan, mengambil keputusan, konflik, dan pembelajaran. Kesulitan dalam memahami sesuatu yang rumit, dengan adanya fasilitasi, dapat dipermudah atau dibuat menjadi tidak terlalu sulit.

Fasilitasi juga dimaksudkan untuk mempermudah kelompok untuk bekerja sama dalam mencapai tujuannya, mempermudah kerja sama antarkelompok, mempermudah dalam menghadapi dan mengelola konflik, serta mempermudah dalam merumuskan rencana kerja.

Fasilitasi diterapkan secara beragam tergantung kepada tujuannya. Dalam konteks pengembangan masyarakat, fasilitasi diterapkan untuk mendorong masyarakat membantu dirinya dengan cara hadir bersama mereka, mendengarkan, dan menanggapi kebutuhannya. Fasilitasi juga diterapkan untuk mendukung individu, kelompok atau organisasi melalui proses-proses partisipatif.

Dalam forum SL, fasilitasi dilihat sebagai sebuah pendekatan untuk mempermudah para peserta meraih tujuannya melalui proses yang adaptif dan dikembangkan berdasarkan prinsip-prinsip utama SL.

Mengapa dalam pembelajaran bersama dibutuhkan fasilitasi? Tiga alasan mendasar terletak pada: tujuan pembelajaran bersama untuk perubahan sosial, keragaman peserta, dan aspek fungsi fasilitasi dalam proses belajar bersama pada arena SL.

Pembelajaran bersama yang dikembangkan dalam SL bukanlah tujuan, melainkan salah satu langkah untuk mendorong terwujudnya perubahan sosial. Perubahan sosial menjadi tujuan utamanya, dan diharapkan, hal itu terjadi melalui pembelajaran bersama. Siklus pembelajaran bersama yang telah bergulir dalam tujuh putaran SL menunjukkan tiga hal penting:

- Perancangan proses-tujuan yang akan dicapai, bagaimana belajar bersama berlangsung, dan apa yang akan dipelajari,

- Pelaksanaan proses-bagaimana melakukan perubahan,

- Refleksi-perubahan apa yang telah dilakukan dan bagaimana menikmati perubahan itu.

Hubungan yang kuat antara pembelajaran bersama dengan perubahan sosial digambarkan dalam siklus yang lentur dan tidak linier. Salah satu alasan yang sering dikemukakan, pembelajaran bersama multipihak membuka interaksi sosial di antara beberapa individu atau kelompok yang berlainan. Cara belajar seperti itu, jauh lebih efektif dalam menghasilkan pengetahuan baru, sikap baru, serta 
ketrampilan baru, yang dibutuhkan dalam melakukan perubahan sosial. Fasilitasi dibutuhkan untuk mempermudah para pelopor perubahan (agent of change) dalam mencapai tujuannya.

Fasilitasi juga dibutuhkan oleh kelompok pembelajar yang hanya terfokus pada substansi dan pencapaian tujuan, tapi kurang peduli pada prosesnya. Dalam SL, peserta merupakan individu-individu dengan latar belakang pendidikan, pengalaman, kelembagaan, sosial-budaya, dan kepentingan yang beragam. Sebagai pelopor perubahan, mereka membangun interaksi sosial, merubah informasi menjadi pengetahuan, menemu-kenali permasalahan dan jalan keluarnya, menyusun rencana, membuat keputusan-keputusan, memberi dan menerima umpan balik.

Proses seperti itu sebenarnya dapat berlangsung tanpa kehadiran fasilitator, tetapi diperlancar oleh keterlibatannya. Fasilitasi menjadi bagian penting dari pembelajaran bersama untuk perubahan sosial: menciptakan sebuah keadaan di mana kelompok-kelompok lebih siap menghadapi perubahan, kerumitan, ketidakpastian, dan konflik. Sejumlah manfaat utama fasilitasi dalam kegiatan SL adalah:

- Fasilitasi memungkinkan pertemuan individu-individu yang beragam untuk saling berbagi pengalaman, bekerja sama, melakukan tindakan yang tidak dapat dilakukan sendiri, dan membantu mereka untuk mencapai tujuannya,

- Fasilitasi dibutuhkan agar para peserta dapat belajar secara kreatif, mengembangkan cara berpikir baru, dan menumbuhkan inovasi yang tiada henti,

- Fasilitasi dapat membangkitkan partisipasi sepenuh hati dari para peserta. Dengan membuka kesempatan yang setara bagi setiap orang untuk mengaktualisasikan diri, dan merasakan manfaat keberadaannya, dalam suatu kerja sama tim, maka fasilitasi dapat membantu untuk meningkatkan produktivitas pembelajar,

- Fasilitasi menentukan pembelajaran multipihak akan lebih berhasil-guna dan berdaya-guna. Meski hampir dapat dipastikan akan selalu diwarnai dengan konflik dan salah tafsir, namun peningkatan kapasitas dapat diraih lebih cepat. Keragaman yang ada diramu menjadi sebuah kekuatan yang mendorong para peserta untuk menyepakati keputusan yang bermutu, dan sekaligus, mendukungnya. 


\section{Nilai-nilai Dasar Fasilitasi dalam Shared Learning}

Fasilitasi pembelajaran bersama digerakkan oleh hakekat yang mendasari seluruh proses dalam forum SL, antara lain, partisipatif, pembelajaran bagi orang dewasa, apresiatif, dan berdasarkan pengalaman. Dari sini, diperoleh intisari nilai-nilai dasar fasilitasi proses belajar SL, antara lain:

- Mendorong perubahan sosial. SL bukan tujuan, melainkan pendekatan untuk mendorong terjadinya pembelajaran sosial bagi perubahan sosial. Peserta SL adalah orang-orang terpilih (sekurang-kurangnya, karena potensinya) untuk merintis perubahan atau, setidaknya, dapat memulai perubahan di kelompok sosialnya sendiri.

- Mempertimbangkan dampak yang luas. Setiap individu harus merasakan manfaat nyata dari kehadirannya, dan diakui keberadaannyapengalaman, pengetahuan dan ketrampilan-sepanjang proses belajar bersama. Pembelajaran bersama diusahakan benar-benar bermakna bagi diri peserta, kelompok, dan pihak lainnya.

- Fokus pada proses dan hasil. Perubahan sosial membutuhkan waktu yang panjang dengan proses yang adaptif. Pembelajaran bersama hanya satu langkah yang harus terus digulirkan di berbagai tingkatan dan kesempatan. Proses pembelajaran adalah upaya yang dilakukan secara terus-menerus. Hasil belajar tetap penting, tetapi bukan berarti 'kejar setoran' demi mencapai hasil yang, akhirnya, menjadi sebuah kegiatan 'tabrak lari' tanpa menghiraukan siklus pembelajaran sosial.

- Bertumpu pada pengembangan aksi. Para pihak berkumpul membentuk kelompok pembelajaran adalah sebuah aksi nyata. Tetapi tindakantindakan lain untuk menyelesaikan masalah yang berdasarkan kebutuhan juga memiliki nilai penting yang sama. Pengembangan mikrohidro (listrik skala kecil), penguatan institusi, pengembangan jaringan pemasaran hasil hutan nonkayu, merupakan contoh-contoh nyata dari tindakan yang dibutuhkan untuk menjawab permasalahan yang ada. Pada sisi lain, hal itu juga menunjukkan adanya perubahan yang dilakukan dalam kerangka pembelajaran bersama. Tetapi, penyelesaian masalah harus dirumuskan secara inklusif melalui perundingan; bahkan, mesti melibatkan pihakpihak yang sesungguhnya tidak memiliki kepentingan langsung. 


\section{Fasilitator dalam Shared Learning}

Fasilitator bekerja di berbagai tingkatan dan tempat, di dalam dan di luar sesi-sesi resmi SL, dalam obrolan dua orang atau lebih, dalam kelompok kecil dan besar, di lapangan dengan kelompok masyarakat, atau bahkan, dalam obrolan santai dengan tuan rumah di mana fasilitator menginap. Fasilitator juga menjadi bagian tak terpisahkan dari proses pembelajaran SL. Dalam SL, fasilitator sekaligus juga menjadi individu yang turut belajar.

Peran fasilitator menjadi salah satu faktor utama yang menentukan keberhasilan proses perjalanan belajar bersama sepanjang SL. Media belajar bersama SL menempatkan fasilitator berperan sebagai:

- Pemandu proses dan pemantik semangat belajar,

- Mendorong peserta untuk reflektif dalam berbagi pengalaman,

- Kreatif dan inovatif dalam membuat rencana, mengambil keputusan, dan memecahkan masalah bersama-sama.

Karena itu, fasilitator dituntut untuk mampu meramu berbagai metode, teknik, dan alat fasilitasi lainnya, sehingga proses belajar bersama menjadi arena yang nyaman, menyenangkan, efektif, dan produktif. Tiga peran utama fasilitator yang membedakannya dengan kelompok peserta dan tim penyelenggara adalah:

- Perancang proses pembelajaran. Merancang proses menjadi tugas utama fasilitator. (Lihat Bab II). Rancangannya menjadi panduan bagi semua pihak untuk bekerja. Tujuan pembelajaran memang harus diraih oleh para peserta, tetapi rancangan proses menentukan arah pembelajaran dan, sekaligus, membuka jalan bagi peserta meraih tujuannya. Agenda yang buruk akan membuahkan proses pembelajaran yang buruk pula, dan sebaliknya. Sebagai perancang proses, fasilitator memiliki kesempatan untuk membantu pihak lain memahami bagaimana merancang dan mengelola berbagi pengalaman, membuat kesimpulan, menemu-kenali masalah, serta membuat keputusan. Alur atau langkah-langkah dalam proses pembelajaran dikembangkan berdasarkan berbagai pertimbangan, antara lain, konsep, tema pembelajaran, jumlah dan keragaman peserta, waktu, kondisi tempat belajar, serta ketersediaan dana. Karena rancangan proses bersifat adaptif-dapat disesuaikan/diubah sepanjang tetap memperhatikan pencapaian tujuan, maka fasilitator harus memiliki kesiapan terhadap lahirnya gagasan dan agenda baru yang tak terduga. Fasilitator di sini, diharapkan, senantiasa menghadirkan proses belajar yang terbuka, inklusif, dan adil, sehingga setiap peserta berpartisipasi 
secara sungguh-sungguh, seimbang; dan, membangun ruang belajar bagi semua pembelajar.

- Pengelola proses pembelajaran. Peran sebagai pengelola proses sama pentingnya dengan perancang proses. Bagaimanapun juga, para pembelajar diundang dan berkumpul membentuk sebuah kelompok dengan kecenderungan hanya pada isi atau substansi pembelajaran, namun kurang menyadari pentingnya proses. Bisa jadi, para peserta tidak tahu atau tidak peduli terhadap cara memandu proses; atau, mereka memang tidak berada pada posisi untuk itu. Fasilitator, bertugas mengelola proses yang mengawal pembelajaran hingga kelompok mencapai tujuannya. Mengelola proses pembelajaran membutuhkan kemahiran dalam menggunakan metode dan teknik fasilitasi, serta didukung dengan pengetahuan dan sikap seorang fasilitator. Dalam mengawal proses, fasilitator bekerja sama dengan narasumber, dan reviewer. Berbeda dengan narasumber yang sedikit bertanya tapi banyak memberikan jawaban, fasilitator akan banyak bertanya, dan sesedikit mungkin memberi jawaban. "Fasilitator memberikan segalanya, kecuali jawaban," demikian sebuah adagium yang sering dikumandangkan oleh banyak fasilitator. Jika seorang fasilitator tidak diperkenankan memberitahu apapun kepada pihak yang difasilitasi, lantas bagaimana dengan keahlian atau ketrampilan yang dimiliki oleh si fasilitator? Kuncinya, harus selalu diingat bahwa peran-peran di atas bukan berarti melarang sama sekali fasilitator untuk menularkan keahliannya. Fasilitator tetap bisa melakukannya dengan 'melepas' perannya sebagai fasilitator terlebih dahulu. Salah satu yang membedakannya dengan narasumber adalah terletak pada frekuensi dan jenis pertanyaan serta jawaban yang disampaikan. Dalam SL, fasilitator juga mengemban peran lain, yaitu sebagai process educator, pendidik proses. Keindahan sebuah fasilitasi terletak pada prosesnya.

- Penyedia dan pengembang alat bantu. Peran ini dilaksanakan agar metode dan alat bantu yang disediakan dapat membantu kelompok lebih mudah, cepat, dan nyaman dalam belajar. Di sini, kemampuan fasilitator meramu metode, teknik dan alat bantu fasilitasi memegang peranan penting bagi keberhasilan proses belajar. Dalam SL, kelancaran proses sangat penting karena setiap peserta akan diajak melalui siklus pembelajaran, mulai dari berbagi pengalaman, refleksi atas pengalaman, berbagi pengetahuan baru hingga menguji-coba pengetahuan tersebut di lapangan. Siklus ini akan mendorong pembelajar untuk memahami bahwa proses belajar bukan hanya menerima pengetahuan, tetapi juga menciptakan pengetahuan baru yang kontekstual bagi dirinya. 


\section{Sikap dan Ketrampilan Fasilitator}

Sikap dan ketrampilan fasilitator laksana 'rumah fasilitasi berlantai tiga'. Sikap-sikap dasar seorang fasilitator berada pada pondasi 'rumah' sedangkan lantai-lantainya merupakan ketrampilan yang perlu dikuasainya. Kemampuan fasilitator terletak pada kemahirannya dalam mendukung suatu kelompok untuk 'membangun rumah' mereka sendiri secara bertahap, dari satu lantai ke lantai berikutnya. Fasilitator tidak bertanggung jawab menentukan bentuk akhir 'rumah' yang dirancang. Fokus fasilitator adalah memperhatikan semua 'lantai' dan 'anak tangga' telah terlewati dan tidak ada yang terlupakan.

Sikap adalah kombinasi dari nilai-nilai, keyakinan dan pendapat seseorang yang terbentuk melalui jalan panjang pengalamannya. Sikap seorang fasilitator dapat terlihat dari kata-kata, pendapat, nada suara, bahasa tubuh, perilaku, raut muka, dan lain sebagainya. Sikap merupakan dasar bagi seseorang untuk menjadi fasilitator, terutama dalam memfasilitasi proses belajar bersama dengan pembelajar yang berlatar belakang berbeda-beda.

Seorang fasilitator harus bersikap positif. Dia harus membuka saluran komunikasi multi-arah dengan berbagai metode dan cara, agar proses pembelajaran bersama dapat berjalan efektif. Sikap-sikap dasar seorang fasilitator sangat menentukan perjalanan dari proses komunikasi itu. Pada intinya, ada empat sikap dasar yang perlu dibangun oleh seorang fasilitator pembelajaran bersama: membuka diri untuk menerima pelajaran, berpikir positif dan apresiatif, empatik, dan percaya sepenuh hati pada potensi kelompok.

- Membuka diri untuk menerima pelajaran. Keanekaragaman pengalaman, pikiran, gagasan, dan nilai-nilai setiap orang atau kelompok menjadi salah satu kekuatan SL. Fasilitator harus memberi teladan untuk menghargai keragaman itu dan membuka diri menerima pelajaran yang mungkin berbeda atau bahkan, bertabrakan dengan pemahaman dan nilai-nilai yang dianutnya. Dalam hal ini, fasilitator harus bisa melepaskan diri dari asumsi serta pandangan orang lain dan harus bekerja keras menempatkan dirinya pada posisi pembelajar. Dengan mengembangkan sikap ini, fasilitator akan mendapatkan kepercayaan dari peserta. Kenetralan fasilitator terhadap substansi yang dipelajari menjadi tantangannya. Meskipun pada kenyataannya tidak ada jaminan bahwa fasilitator selalu berada atau mampu berada pada "sudut netral" itu, fasilitator diharapkan dapat menahan diri dalam mencampuri substansi. Fasilitator harus dapat membuka, mengenal dirinya, dan menyadari posisinya terhadap 'sudut netral' tersebut. Dalam mengembangkan sikap membuka diri, fasilitator 
juga akan berhadapan dengan kehendaknya (yang bisa muncul tiba-tiba, dan liar tak terkendali) untuk memiliki kepentingan atas hasil yang akan dicapai. Ketika fasilitator tidak membebaskan diri dari kepentingannya atas substansi, terjadilah manipulasi fasilitasi: "Nampaknya kelompok telah keliru menarik kesimpulan, seharusnya kesimpulannya adalah.... Dalam contoh lain, "Menurut saya prinsip-prinsip yang telah kalian susun masih belum lengkap. Sebaiknya, ditambah dengan prinsip ini dan prinsip itu...." Inilah 'fasipulasi', fasilitasi-manipulasi. Banyak kiat yang dapat digunakan untuk mengatasi godaan itu. Antara lain, dengan mengajukan pertanyaan-pertanyaan reflektif kepada peserta, membuka ruang dialog dan melakukan reframing dari pengalaman-pengalaman yang ada.

- Berpikir positif dan apresiatif. Sesuai dengan pendekatan appreciative inquiry yang digunakan dalam SL, maka fasilitator harus mengawali segala sesuatunya dengan berpikir positif, apresiatif, dan berorientasi ke depan. Berpikir positif terhadap keseluruhan isi, proses dan dinamika kelompok, pada dasarnya, untuk membantu pembelajar mencapai tujuannya. Hal ini berarti, apapun pandangan, pendapat, perilaku, ataupun latar belakang seseorang, fasilitator harus selalu menghormati keunikan dan potensinya. Tetapi, dengan bersikap positif dan apresiatif bukan berarti menumpulkan daya kritis dan analitis.

- Empatik. Empati adalah sebuah sikap dengan menempatkan diri dalam situasi yang dihadapi peserta belajar bersama. Sikap ini hanya dapat dibangun dengan membuka diri (hati dan pikiran) dan menunjukkan minat atau ketertarikan yang tinggi kepada materi yang dibahas, latar belakang pembelajar, dan proses yang akan berlangsung. Nilai penting sikap ini bagi fasilitator adalah dalam kerangka memahami perspektif orang lain terhadap isu tertentu, keanekaragaman kondisi, situasi, dan kepentingannya. Sikap empatik, pada akhirnya, akan menyentuh emosi/ perasaan peserta. Jika mereka merasa dihargai keberadaannya, dan disimak pendapatnya, maka hal itu dapat mendorong kelompok untuk lebih memiliki rasa percaya diri, atau menjadi dirinya sendiri, dalam berbagi pengalaman. Proses berbagi pengalaman akan mengalir tanpa sumbatan dan setiap pembelajar dapat saling menyimak dengan aktif.

- Percaya sepenuh hati pada potensi kelompok. Kelompok pembelajaran merupakan kumpulan dari individu-individu terpilih di bidangnya. Mereka adalah para pelaku yang memiliki pengalaman empirik, atau sekurangkurangnya, orang yang paling memahami tentang persoalan yang dihadapi. Fasilitator harus percaya sepenuh hati bahwa mereka jualah yang paling berpotensi dapat menemukan jalar keluarnya yang kreatif. 
Sementara itu, ketrampilan dasar seorang fasilitator terdiri dari ketrampilan menguasai teknik-teknik non-verbal dan verbal. Teknik non-verbal, yaitu caracara yang harus dilakukan oleh seorang fasilitator dalam memfasilitasi sebuah kelompok belajar. Teknik ini melingkupi:

- Teknik mengamati. Mengamati adalah melihat fakta dengan seksama tanpa melakukan penilaian atas realitas yang disaksikan dan tanpa mencampuradukkan dengan asumsi-asumsi yang dimiliki fasilitator. Dalam memfasilitasi, kemampuan mengamati memerlukan usaha yang besar karena seorang fasilitator mesti melepaskan diri dari cara pandangnya.

- Teknik menyimak. Menyimak adalah mendengarkan secara seksama pernyataan atau perkataan orang lain tentang substansi dan latar belakangnya-perasaan, kepentingan, cara pandang dan perilaku. Menyimak merupakan proses untuk memahami, tanpa menilai salah atau benar, sebuah pernyataan, sehingga fasilitator mendapatkan gambaran utuh dari pesan yang disampaikan. Selain memusatkan pada pesan, fasilitator juga perlu menangkap tanda-tanda non-verbal, seperti tekanan suara, pilihan kata-kata, perubahan raut muka, gerakan tubuh dan kehatihatian penggunaan kata.

- Teknik mengolah bahasa tubuh. Gerakan dan posisi tubuh fasilitator juga dapat menjadi pesan yang bisa dilihat—lebih dikenal sebagai bahasa tubuh. Cara fasilitator berdiri, mengambil posisi, duduk, bergerak dan menggerakkan anggota badan, berpengaruh pada apa yang ingin dikatakan atau dilakukan dan mempengaruhi proses pembelajaran. Cara paling sederhana untuk membuat kelompok merasa nyaman adalah dengan bahasa tubuh yang rileks, seperti: posisi tangan di samping dan terbuka. Posisi tubuh seorang fasilitator harus bisa mendorong semangat belajar, bukan untuk mendominasi forum pembelajaran. Sebaiknya, berusaha untuk tidak selalu berdiri di depan atau di tengah forum. Fasilitator bisa berada bersama peserta saat diskusi kelompok, duduk bersama dan membantu menuliskan di papan tulis.

- Suara dan ekspresi wajah. Suara dan ekspresi wajah fasilitator juga berpengaruh terhadap atmosfer fasilitasi. Pilihan tekanan suara (tinggi atau rendah) dan emotional overtone-semangat, sedih, bosan, takut, was-was-akan menjadi perhatian pembelajar. Karena itu, kemampuan memainkan variasi tekanan suara saat berbicara menjadi penting; khususnya, saat ingin menonjolkan makna-makna tertentu. Begitu juga dalam hal mengatur kecepatan berbicara; terlalu cepat akan melelahkan pembelajar, sebaliknya, bila terlalu lambat juga akan membosankan. 
Di samping itu, ekspresi wajah fasilitator amat mempengaruhi energi kelompok. Fasilitator perlu menunjukkan raut wajah yang sesuai dengan suasana (mood) yang diharapkan bisa mempengaruhi situasi kelompok. Misalnya, kalau fasilitator ingin suasana kelompok santai, terbuka dan penuh perhatian, maka sang fasilitator harus menunjukkan bagaimana ia bersikap santai dan terbuka. Senyum adalah senjata yang ampuh dalam fasilitasi, namun terlalu banyak menebar senyum juga bisa membuat peserta merasa tak nyaman. Fasilitator diperkenankan untuk diam sejenak, khususnya ketika harus berpikir atau merespon sesuatu yang sulit.

- Memberi perhatian dan semangat. Fasilitator hendaknya selalu memberi perhatian dan memompa semangat pihak yang difasilitasinya. Salah satunya, dengan menjaga kontak mata dengan pembelajar yang sedang berbicara. Kontak mata bukan berarti memandangi seseorang terusmenerus, melainkan menatap si pembicara dengan cara yang santai. Kontak mata memiliki kekuatan untuk memberikan perhatian pada seseorang. Hanya saja, perlu berhati-hati karena pada kebudayaan tertentu, menatap lawan jenis atau orang yang lebih tua terkadang dianggap tidak sopan. Energi seorang fasilitator bisa mempengaruhi suasana fasilitasinya. Energi positif dan penuh semangat akan menyebar ke seluruh peserta, begitu juga sebaliknya. Menularkan semangat harus dimulai dengan menunjukkan semangat dari fasilitatornya, baik melalui suara, gerak tubuh, ekspresi wajah, ataupun dengan menciptakan permainan-permainan sederhana dan singkat. Dalam keadaan tertentu, tepuk tangan, lelucon atau humor dapat pula dilakukan untuk memberi semangat. Hanya perlu dibatasi agar suasana belajar tetap terjaga.

- Menghindari kebiasaan buruk. Terkadang, fasilitator tidak menyadari kebiasaan yang dilakukan berulang-ulang bisa menganggu kenyamanan pembelajar. Kebiasaan itu, misalnya, gemerincing kunci/uang receh di saku, memainkan pulpen, menggaruk-garuk tangan, mengupil, memindahkan kertas atau barang tanpa tujuan dan lain-lain. Kebiasaan buruk ini dilakukan tanpa sadar sehingga sulit bagi fasilitator untuk menyadarinya. Untuk itu, fasilitator perlu membiasakan diri meminta orang lain memberi umpan balik (personal feedback) atas proses fasilitasinya.

Teknik verbal, yaitu hal-hal yang harus dituturkan oleh seorang fasilitator. Teknik ini mencakup:

- Teknik membuat ikhtisar (Paraphrasing). Ikhtisar adalah menuturkan kembali pernyataan orang lain dalam bahasa yang lebih sederhana dan komunikatif tanpa menghilangkan atau mengubah makna aslinya. 
Selain bermanfaat untuk memastikan pemahaman fasilitator, ikhtisar juga memberi kesempatan kepada pembelajar lain untuk memeriksa penafsirannya terhadap sebuah pernyataan. Pada saat yang sama, peserta yang berbicara juga dapat menjelaskan pendapatnya dengan lebih tepat atau, jika belum jelas, berkesempatan mengoreksinya. Teknik ini harus digunakan saat benar-benar diperlukan; misalnya, ketika sedang merekam gagasan peserta pada kertas plano. Seni ikhtisar tidak digunakan untuk mengoreksi gagasan atau pendapat pembelajar ataupun untuk mengubah makna suatu pernyataan.

- TeknikBertanya (Questioning). "Pertanyaanyangindahselalumenghasilkan jawaban yang indah pula," kata E.E. Cummings. Sebaliknya, pertanyaan yang salah akan menghasilkan jawaban yang salah juga. Kemampuan mengajukan pertanyaan yang baik di saat yang tepat dan dengan cara yang tepat merupakan salah satu teknik dasar terpenting dari seorang fasilitator. Pertanyaan terbuka mendorong kelompok mengungkapkan gagasan, pendapat, reaksi atau informasi. Pertanyaan terbuka, jamak dimulai dengan: apa, bagaimana, dan mengapa. Jenis pertanyaan ini, lazimnya, digunakan untuk mendorong kelompok agar berpikir dan berpartisipasi sehingga sangat efektif untuk mengeksplorasi atau menciptakan keterbukaan. Selain itu, juga ada pertanyaan tertutup, yang hanya bisa dijawab dengan 'ya' atau 'tidak'; atau satu-dua kata lainnya, tergantung pada pertanyaan yang diajukan. Jenis pertanyaan ini bermanfaat untuk mencari fakta dan memandu kelompok dalam mengerucutkan gagasan dan konfirmasi. Biasanya dimulai dengan kata tanya: siapa, kapan, dan di mana. Tak jarang, jenis pertanyaan ini juga dapat menjadi alat untuk mengarahkan pembelajar. Perlu berhati-hati dalam pemakaiannya, terlalu banyak pertanyaan tertutup bisa membuat peserta putus asa, defensif, dan menciptakan suasana negatif. Karenanya, dalam mengajukan sebuah pertanyaan, fasilitator perlu mengembangkan sikap-sikap: sabar, bertanya secara kritis tapi bukan untuk mengkritik, bertanya secara positif, dan mengajukan pertanyaan yang bersifat menguji, bukan untuk melihat seseorang bodoh atau pintar.

- Teknik menggali informasi (Probing). Probing adalah ketrampilan dasar untuk menggali lebih jauh suatu gagasan atau pikiran seseorang. Ketrampilan ini dilakukan untuk membantu memahami lebih mendalam pernyataan pembelajar. Hal ini diperlukan mengingat fakta bahwa kecepatan berpikir setiap orang adalah 800 kata per menit sedangkan kemampuan berbicara hanya 120 kata per menit. Teknik ini digunakan untuk mendapatkan lebih banyak informasi dan mendorong pembelajar 
lebih banyak berdiskusi. Teknik ini dapat membantu kelompok dalam: mencari akar masalah, membantu orang lain memahami lebih jauh, dan mendorong peserta berpikir lebih mendalam. Sangat penting mengetahui kapan sebaiknya teknik ini digunakan. Jika diterapkan secara terbuka dan hati-hati, probing sangat penting dan bermanfaat. Sebaliknya, bila dilakukan berlebihan bisa membuat peserta merasa diinterogasi atau ada pembelajar lain yang merasa diabaikan. Di samping itu, fasilitator juga terlihat tidak netral atau arah diskusi malah tidak jelas.

- Teknik mendorong orang berbicara (Encouraging). Di dalam proses belajar bersama, keanekaragaman latar belakang peserta, selain menjadi faktor pendukung, juga memberi tantangan tersendiri bagi fasilitator. Tak jarang pembelajar dari masyarakat lebih banyak memilih diam dalam sebuah pertemuan dibandingkan pembelajar dari pemerintahan ataupun lembaga swadaya masyarakat (LSM). Lantaran itu, mendorong semua orang untuk berbicara menjadi ketrampilan dasar yang penting bagi tercapainya partisipasi penuh dari para pembelajar.

- Teknik membuat kesimpulan (Summarizing). Ketika para peserta sudah merasa bebas berbicara, tak jarang pembicaraannya justru melebar dari sebelumnya. Ketrampilan membuat kesimpulan dari pendapat pembelajar, selain membantu fasilitator mengerti maksudnya, juga memudahkan peserta lain untuk turut memahaminya. Cara mudah membuat kesimpulan adalah dengan mengambil kata-kata kunci dari subyek pembicaraan. Namun, perlu berhati-hati untuk tidak menyederhanakan pemikiran seseorang.

\section{Kiat Mengatasi Rintangan Fasilitasi Belajar Bersama}

\section{Sikap Fasilitator}

Karakter fasilitator sangat beragam. Watak pemandu proses dipengaruhi oleh cara pandang, pengetahuan, sikap, dan keterampilan yang dimilikinya. Meskipun tim fasilitator dibentuk melalui proses seleksi, dan diskusi untuk membangun pemahaman yang sama, tetapi selalu terbuka celah adanya penafsiran yang berbeda tentang hakikat dari forum SL. Sikap dasar yang harus dimiliki oleh fasilitator selalu menjadi bahan pertimbangan utama dalam membentuk tim fasilitator. Pandangan yang salah tentang hakikat proses belajar SL akan menghasilkan sikap yang 
keliru pula. Akan tetapi, karakter yang beragam akan menjadi kekuatan, jika tim fasilitator menempuh jalan menuju kolaborasi yang kokoh. Di situlah pentingnya membangun, memperkuat, dan menumbuhkan saling menghargai dalam tim fasilitator. Kerja sama yang kokoh dalam tim ini, akhirnya, akan menentukan kemampuannya dalam memfasilitasi; khususnya, ketika peserta membutuhkan bantuan fasilitator dalam memperkuat kerja sama di antara mereka.

\section{Krisis Kelompok}

Dalam tujuh kali penyelenggaraan SL terlihat, minat para pihak untuk mengikuti kegiatan ini cukup tinggi. Jumlah pembelajar selalu saja membengkak melebihi 40 orang dan sebagian besar bertahan hingga akhir kegiatan. Pada satu sisi, hal itu menggembirakan, tetapi pada sisi lain mencemaskan bagi proses fasilitasi dan penyelenggaraan SL. Seiring dengan bertambahnya peserta, semakin beragam pula latar belakang sosial-budaya dan gaya belajarnya. Begitu juga, tantangan dalam memfasilitasinya juga kian besar. Dibutuhkan proses fasilitasi tingkat tinggi yang didukung dengan seluruh kehandalan para fasilitatornya. Jumlah pembelajar ideal yang dapat dikelola akan tergantung pada banyak aspek. Jumlah peserta yang melebihi batas kemampuan pengelolaan, dalam beberapa kasus, bisa mengakibatkan krisis kelompok. Kelompok tidak berfungsi lagi sebagai sebuah tim (teamwork) dan proses pembelajaran tidak berlangsung lancar.

Krisis kelompok dapat terjadi ketika ada pembiaran adanya dominasi, konflik, resistensi, krisis kepercayaan, saling menegasikan, dan buruknya hubungan personal antarpeserta. Keberhasilan tim dalam bekerja sama dan meraih tujuan, pada akhirnya, ditentukan oleh sikap berbagi, saling membantu, dan memberi yang terbaik bagi proses pembelajaran. Pembagian dalam kelompok-kelompok yang lebih kecil, tanpa membatasi intensitas interaksi antar-pembelajar, akan sangat membantu mengurangi krisis kelompok. Pengalaman menunjukkan, untuk menumbuhkan kekompakan kelompok perlu pengembangan tim (team building) sejak dini, jika perlu sejak hari pertama SL.

\section{Dilema Waktu}

Cara belajar yang kreatif membutuhkan waktu. Tetapi waktu juga selalu terbatas. Alat bantu fasilitasi: jurnal, review film dan foto, bahan bacaan, majalah dinding, permainan untuk bina suasana, dan pemilihan metode, dikembangkan untuk membantu kelompok dalam menegaskan kembali hal-hal yang dipelajari. Hal 
itu juga berguna untuk mengatasi kebosanan, meningkatkan minat dan gairah belajar, menikmati manfaat kehadiran peserta, dan memotivasi kelompok untuk mencapai tujuannya. Hal itu juga dilakukan untuk memberi ruang yang memadai bagi kelompok dalam mengembangkan interaksi yang apresiatif dan sikapsikap yang mendukung proses pembelajaran. Penyelenggaraan SL yang terlalu lama (lebih dari sembilan hari, misalnya), selain berdampak membengkaknya pembiayaan, juga kurang memungkinkan bagi keterlibatan pihak-pihak tertentu (pejabat atau ibu rumah tangga). Dibutuhkan proses belajar kreatif yang efektif dan efisien. Masalahnya, kecenderungan kolektif dalam keadaan "miskin" waktu, bukannya berhemat tetapi malah boros waktu. Dalam keadaan waktu yang semakin terbatas, peserta cenderung 'kejar setoran': mengutamakan hasil dan mengabaikan proses. Padahal, proses dan hasil sama-sama bernilai penting. Tata kelola waktu, pengawalan jadwal oleh penjaga waktu, disiplin, dan pemilihan metode fasilitasi yang tepat, merupakan beberapa hal yang penting untuk dilakukan, agar proses pembelajaran lebih efisien dan tetap berlangsung secara kreatif. 



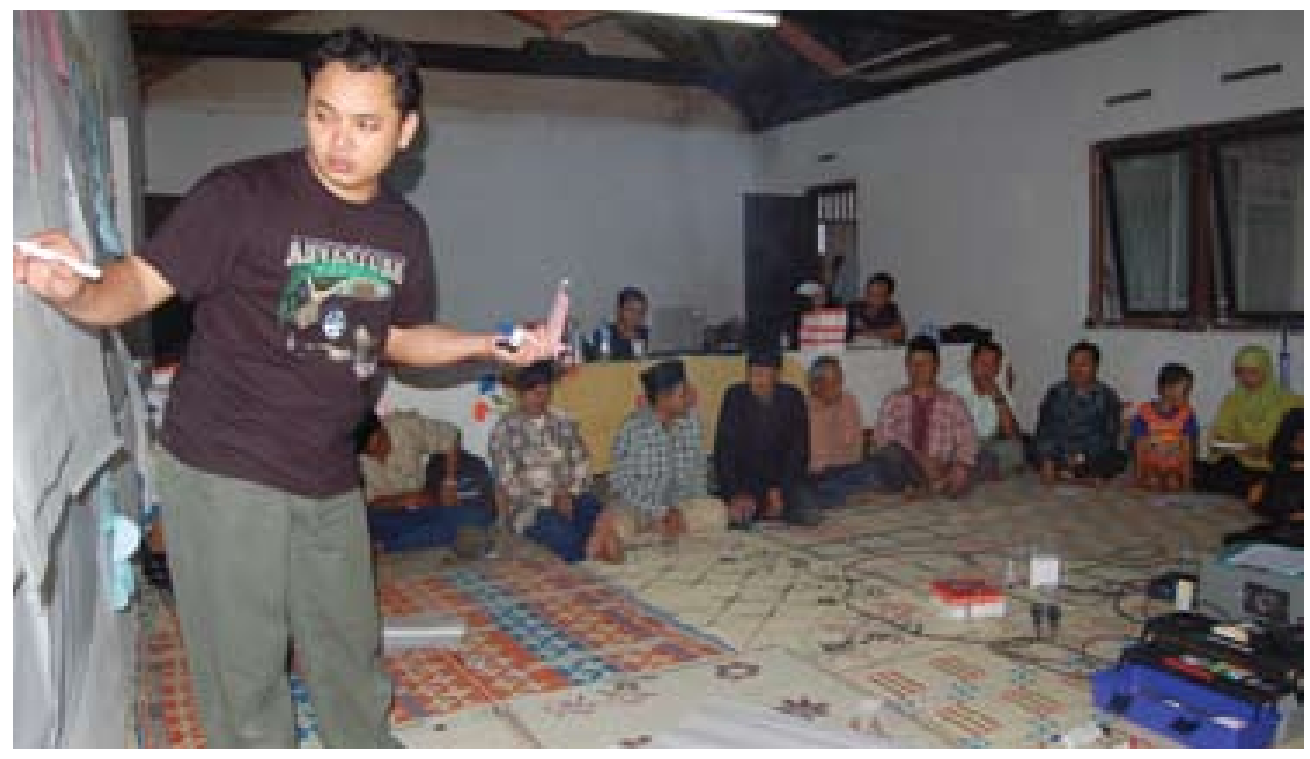

Untuk mewadahi semua pengalaman dan pengetahuan peserta, forum $S \mathcal{L}$ menerapkan berbagai metode dan teknik Gelajar bersama. Saat kajian desa, pembelajar memiliki Kesempatan menumpahkan segala pengetahuannya untuk Gelajar secara interakțif Gersama warga setempat. 


\section{BAB 4}

\section{Metode dan Teknik Belajar: Memetik Pengalaman Bersama}

Dalam forum Shared Learning (SL) terdapat dua tingkat proses pembelajaran yang dijalankan. Pertama, proses belajar di dalam ruangan, dan kedua, pengkajian lapangan. Kedua proses belajar itu bersifat saling melengkapi dan saling mempengaruhi satu sama lain.

Secara umum, proses belajar SL memerlukan metode dan teknik belajar yang bisa memudahkan peserta mencapai tujuannya. Dengan demikian, metode dan teknik fasilitasi harus mencakup dua proses belajar tersebut, antara lain: memandu proses belajar dan pengkajian lapangan.

\section{Memandu Proses Belajar}

Tim fasilitator SL perlu merancang proses belajar yang kreatif, tidak membosankan, dan bisa mendorong pembelajar mencapai tujuannya. Termasuk di dalamnya, 
menentukan berbagai metode dan teknik fasilitasi proses belajar. Meski banyak metode dan teknik yang bisa digunakan, yang terpenting adalah proses fasilitasi bisa mengantarkan dan memudahkan peserta mencapai tujuannya. Berikut ini beberapa metode yang biasa digunakan dalam proses SL.

\section{Mengenal Diri Sendiri}

Mengenal diri sendiri dimaksudkan agar pembelajar memahami potensinya dan, pada saat yang sama, memahami potensi peserta lainnya. Pengenalan diri menjadi modal bagi peserta untuk belajar bersama pada sesi-sesi selanjutnya dalam forum SL. Fasilitator bisa menggunakan teknik-teknik psikologi yang sudah ada, misalnya tes MBTI (Myers-Briggs Type Indicator). Meskipun begitu, dalam penerapannya perlu dilakukan secara bijak. Fasilitator juga bisa menambah informasi tentang berbagai fakta berkaitan dengan otak manusia, proses belajar orang dewasa, gaya orang belajar, dan sebagainya, yang bisa mendorong semangat belajar.

\section{Seminar}

Sejumlah pakar atau orang yang ahli dalam bidang tertentu membagikan pengetahuannya tentang isu tertentu terkait tema SL. Dalam setiap seri SL, biasanya, tiga hingga empat orang ahli menjadi pembicara dalam sesi ini. Tujuan seminar ini untuk meningkatkan kedalaman pengetahuan peserta mengenai isu terkait. Fasilitator berperan memandu proses jalannya diskusi yang memperlancar alih pengetahuan.

\section{Pembekalan}

Metode ini dimaksudkan untuk memberikan bekal ketrampilan kepada peserta dalam menggunakan berbagai metode dan teknik pengkajian dinamika alam dan sosial kemasyarakatan. Tidak menutup kemungkinan berbagai ketrampilan teknis diberikan kepada peserta dalam sesi ini-misalnya, ketrampilan menggunakan peralatan geographic positioning system (GPS). Pembekalan ini diberikan sebelum pembelajar melakukan kajian lapangan. Beberapa ahli yang menguasai metode dan teknik terkait difasilitasi untuk bisa menularkan ketrampilannya kepada peserta. 


\section{Berbagi Pengalaman dari Berbagai Lokasi}

Peserta dapat menebar pengalamannya kepada yang lainnya; dan, pada saat yang sama, pembelajar juga dapat belajar dari pengalaman peserta lainnya. Untuk berbagi pengalaman, peserta bisa memanfaatkan berbagai media yang ada; misalnya, presentasi dengan powerpoint, poster-poster yang menarik, film dokumenter yang inspiratif maupun makalah. Jauh-jauh hari sebelum pelaksanaan SL, pembelajar telah diminta untuk memilih media untuk berbagi pengalamannya. Peserta diberi kebebasan untuk menentukannya. Informasi keragaman media presentasi dari pembelajar membantu tim fasilitator dalam menentukan metode berbagi pengalaman yang pas. Satu hal yang terpenting: pembelajar bisa membagikan pengalamannya, sementara peserta yang lain mampu menangkap materi yang disampaikan. Fasilitator bertugas membangun terjadinya dialog yang menarik.

\section{Klinik}

Metode ini digunakan untuk memberikan ruang kepada peserta yang tidak puas dengan metode seminar dan berbagi pengalaman. Seringkali peserta mempunyai pertanyaan spesifik dan ingin mengkaji lebih mendalam dengan seorang pakar. Dalam metode ini, disiapkan beberapa ahli sebagai 'dokter' yang menguasai persoalan terkait dengan tema SL. Peserta, layaknya seorang 'pasien', bisa berdiskusi satu persatu dengan 'dokter' tersebut. Fasilitator berperan mengatur tata waktu sehingga para pembelajar mempunyai kesempatan yang sama; sebagai alternatif, bisa juga peserta dibagi dalam beberapa kelompok kecil yang membahas masalah tertentu.

\section{Tinjauan Reviewer}

Reviewer, atau pengamat, di dalam proses SL berperan untuk mengamati jalannya proses belajar, dan memberikan tinjauan atau pendapatnya, baik harian maupun seluruh proses pembelajaran di akhir kegiatan. Biasanya, diperlukan satu sampai dua orang reviewer setiap kali kegiatan SL. Pengamat akan memberikan tinjauannya tentang bagaimana substansi dipelajari, bagaimana proses belajar berlangsung, apa yang mesti diperbaiki, dan hal-hal lain yang terkait dengan proses pembelajaran. Pengamat sebaiknya orang yang telah mengetahui substansi tema SL dan mempunyai pemahaman yang baik tentang proses belajar bersama. 


\section{Film Dokumenter}

Media audio-visual mempunyai kekuatan tersendiri sebagai bahan belajar bersama. Film dokumenter mengenai isu-isu terkait dengan tema SL, misalnya, bisa menjadi media menarik yang akan merangsang peserta untuk lebih memahami persoalan. Film-film yang inspiratif, seperti The Inconvenient Truth, Our Planet ataupun film dokumenter dari para peserta, bisa lebih cepat mempengaruhi perasaan dan menghadirkan inspirasi segar untuk belajar. Setelah film diputar, peserta bisa berdiskusi tentang tema film dan direfleksikan ke dalam konteks lokal. Fasilitator berperan menciptakan suasana segar untuk diskusi.

\section{Jurnal Harian, Rekaman Foto dan Video}

Sepanjang proses SL, penting sekali untuk melakukan refleksi atas hal-hal yang sudah dipelajari bersama. SL menggunakan jurnal harian, penayangan foto, dan video untuk membantu peserta berefleksi. Jurnal harian berisi berita dan halhal penting yang sudah dicapai pada hari sebelumnya. Demikian juga rekaman foto dan video yang menayangkan kegiatan peserta di hari sebelumnya. Tujuan dari metode ini, menyediakan bahan refleksi bagi peserta dengan membaca dan melihat kembali proses yang telah dilewati. Dengan demikian, diharapkan proses selanjutnya akan lebih baik dan bersemangat. Jurnal harian, rekaman foto dan video turut melengkapi review dari pengamat.

Keberhasilan memandu proses belajar sangat berpengaruh terhadap lancarnya seluruh pembelajaran selama SL. Perlu disadari, semua rangkaian metode di atas ditujukan untuk mempermudah peserta untuk mendapatkan pengetahuan baru sekaligus menciptakan suasana belajar yang nyaman.

\section{Kajian Lapangan}

Dalam kegiatan SL, salah satu bagian utamanya adalah kajian lapangan menyangkut tema yang menjadi fokus pembelajaran. Bagian ini dimaksudkan agar peserta melalui aktivitas: mengalami - mengurai - menganalisis - menyimpulkan persoalan sebagai bagian dari proses pembelajaran. Kajian lapangan juga menjadi forum belajar bersama antara peserta dan masyarakat, baik menyangkut tema SL maupun hal-hal lain yang dimungkinkan. 
Pada kesempatan ini pembelajar melakukan pengkajian atas isu yang terkait dengan tema SL, dengan mengambil contoh kasus sekelompok masyarakat yang dikunjunginya. Peserta tinggal di lokasi kajian selama beberapa hari (tiga sampai empat hari) di tengah sebuah komunitas untuk menjalin interaksi dengan penduduk setempat dan saling bertukar pengalaman. Sebelumnya kajian dilakukan, peserta dibekali dengan seperangkat metode dan teknik pengkajian yang relevan.

Sebelum melakukan kajian lapangan, beberapa hal yang harus dilakukan oleh tim penggerak SL adalah:

- Menyiapkan masyarakat setempat di mana kajian akan berlangsung,

- Jika dibutuhkan, bisa membagi kelompok dan mengatur agar ada pembagian tugas di dalamnya,

- Memastikan peserta merancang kajian lapangan dengan baik,

- Memastikan tujuan yang akan dicapai dalam kajian lapangan.

Hal penting lain yang perlu ditekankan, tim fasilitator dan penyelenggara SL harus memandu proses merancang kajian desa. Pemantapan rancangan kajian oleh pembelajar sangat penting karena menjadi panduan bagi peserta untuk belajar di lapangan. Meski begitu, masih dimungkinkan adanya adaptasi rancangan kajian sesuai dengan keadaan lokasi setempat.

Di sinilah, pembekalan metode dan teknik bagi para pembelajar berguna untuk memudahkan mereka belajar di lapangan. Sederhananya, metode bisa dipahami sebagai sekumpulan teknik yang digunakan berdasarkan kaidah-kaidah tertentu untuk mencapai tujuan kajian. Metode memudahkan para pembelajar untuk memetakan, memahami, dan menganalisis berbagai situasi, baik yang bersifat fisik maupun sosial serta hubungan antara keduanya.

Pada dasarnya, metode dan teknik pengkajian sudah banyak diciptakan oleh para ilmuwan dan praktisi sosial sehingga tidak perlu menciptakan metode dan teknik yang baru sama sekali. Nyaris semua teknik dalam metodologi PAR/PRA (Participatory Action Research/Participatory Rural Appraisal) bisa diterapkan.

Demikian juga bisa dipraktikkan metode-metode penggalian informasi secara partisipatif lainnya yang selama ini digunakan dalam penelitian kualitatif. Agar adaptif, tim fasilitator bisa memodifikasi berbagai metode dan teknik yang ada sehingga cocok dengan isu, kondisi lokal, dan tujuan pengkajian.

Tema yang diusung SL biasanya berkaitan dengan hubungan antara manusia dengan sumberdaya alam beserta dinamika di dalamnya. Karena tema pembelajaran bisa 
beragam, dan tingginya dinamika di lapangan, maka tidak ada metode dan teknik baku yang diterapkan dalam kajian lapangan.

Kendati begitu, terdapat beberapa aspek yang perlu diperhatikan untuk memudahkan kegiatan belajar antara peserta dan masyarakat setempat, antara lain:

- Memastikan partisipasi masyarakat dalam proses kajian lapangan, agar terjadi pertukaran pengetahuan antara peserta dengan masyarakat,

- Kajian lapangan tidak mengganggu aktivitas penduduk lokal. Pencarian informasi dalam kajian lapangan sedapat mungkin dilakukan dengan mengikuti gerak kehidupan masyarakat setempat.

Seluruh proses kajian lapangan—fasilitasi, notulensi, pencarian data, informasi, pertemuan dengan masyarakat—dilakukan oleh pembelajar. Tim fasilitator dan panitia hanya mendampingi dan memudahkan proses pembelajaran yang berlangsung. Pada kajian lapangan ini, peran peserta, bersama masyarakat, lebih menonjol dalam pembelajaran. Selain bermodal metode dan teknik yang diperoleh selama SL, para peserta diberi keleluasaan untuk menerapkan semua kemampuannya - ketrampilan fasilitasi dan pengetahuan, dalam menjalankan kajian lapangan.

Pengamat (reviewer) berperan memberikan pandangan atau pendapat atas kajian yang telah dilakukan, sekaligus memberi ruang bagi peserta untuk berefleksi tentang proses kajian lapangan. Refleksi ini penting agar peserta bisa memperoleh gambaran seberapa jauh kajian mendekati tujuan belajar yang hendak dicapai. Masyarakat setempat juga dimungkinkan untuk berpartisipasi memberikan pandangan dan pendapatnya. 



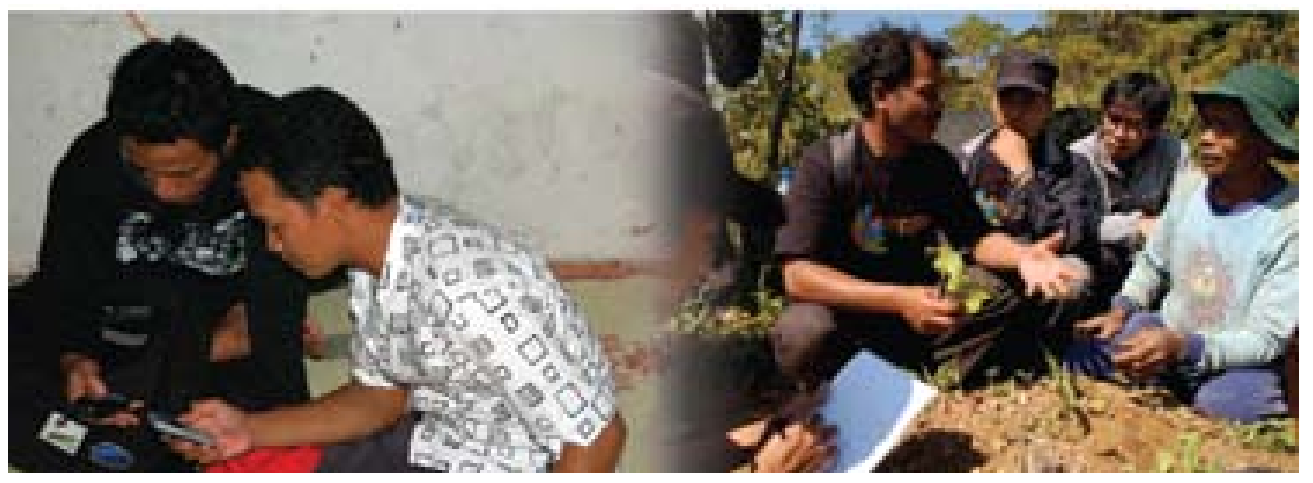

Ber6agi pengetahuan terjadi di mana dan Kapan saja. Ketikga harus berpisah pun, pertukaran ilmu masih dimungkinkan melalui telepon genggam. 


\section{BAB V}

\section{Penutup: \\ Menimbang Buah Shared Learning}

\section{Dampak Shared Learning}

Ketika buku ini disusun, sebanyak tujuh seri Shared Learning (SL) telah diselenggarakan dengan berbagai tema dan lokasi yang berbeda. Kegiatan ini juga telah menghadirkan sekitar 250 peserta yang berasal dari daerah yang berbedabeda. Beberapa peserta telah berpartisipasi sebanyak dua hingga tiga kali dalam ajang SL. Dari merekalah diperoleh kesan mengenai dampak SL bagi alumninya, baik secara individu maupun kelompok, dalam pengelolaan sumberdaya alam di daerahnya. Kendati masih diperlukan kajian yang lebih mendalam untuk menilai dampak ini, namun dalam sebuah refleksi yang pernah dilakukan, ada beberapa hal yang mengemuka, di antaranya:

- Walaupun sebagai konsep dan praktik SL dipahami berbeda-beda oleh para pesertanya, namun ada kesadaran kolektif bahwa SL adalah suatu ajang belajar bersama melalui pengalaman dan berbagi pengetahuan. 
Dalam hal ini, belajar bersama bukanlah tujuan tetapi alat untuk mencapai perubahan,

- Perubahan yang paling awal terlihat adalah di tingkat individu. Sebagian besar peserta mengakui adanya peningkatan pengetahuan yang besar: dari tidak tahu menjadi tahu; awalnya, tidak peduli, menjadi peduli. Hasil paling menggembirakan diperoleh ketika peserta berperan menjadi pelopor perubahan (agent of change) di kelompoknya. (Lihat Kotak 2.). Dengan begitu, pemilihan peserta yang tepat, tidak saja mempunyai pengalaman yang relevan tetapi juga kemampuan untuk mendorong pembelajaran sosial di daerahnya, merupakan kunci kedua keberhasilan SL_-kunci pertama adalah fasilitasi,

- Perubahan individual ini ditandai dengan terjadinya perubahan cara pandang peserta dalam pengelolaan sumberdaya hutan, khususnya tentang hubungan antara hutan dengan masyarakat. Seorang staf balai taman nasional, misalnya, yang terpaku untuk melarang keberadaan masyarakat di dalam kawasan taman nasional, akan terheran-heran menyaksikan masyarakat di sekitar Taman Nasional Gunung Leuser, Sumatera Utara, yang diberi kewenangan mengelola sebagian kawasan melalui aktivitas ekowisata berbasis masyarakat. Terobosan ini memberi wawasan baru bagi staf Balai Taman Nasional Kutai, Kalimantan Timur, yang sedang mencoba mencari pola penyelesaian konflik dengan masyarakat maupun pihak lain di kawasannya.

Kendati beberapa bukti sudah memperlihatkan adanya perubahan di tingkat individu, namun masih perlu dikaji lebih mendalam bagaimana perubahan itu dapat bergulir ke tingkat yang lebih luas. Artinya, bagaimana individu tersebut, dengan bekal pengalaman belajar bersama, memiliki minat dan kemampuan berupaya mempengaruhi kelompoknya-baik di tengah masyarakat, instansi, maupun lembaganya. 


\section{Kotak 2. Shared Learning: Merintis Perubahan.}

Kampung Alexander Burung terletak jauh di pedalaman Kalimantan Barat, bagian hulu Sungai Kapuas, kawasan Taman Nasional Danau Sentarum. Burung, begitu panggilan akrabnya, juga seorang kepala dusun yang tinggal bersama masyarakatnya di dalam sebuah rumah panjang, rumah tradisional Suku Dayak Iban. Kampungnya itu, Sungai Pelaik, disebut begitu karena terletak di tepi Sungai Pelaik. Saking susahnya menjangkau kampung di kaki Bukit Pelaik ini, untuk mengirim undangan Shared Learning (SL) II untuk Burung harus melalui siaran Radio Republik Indonesia (RRI)-Pontianak yang disiarkan selama tiga minggu. Untunglah, Burung rajin mendengarkan siaran RRI setiap sore; dan, sampailah undangan itu.

Burung, akhirnya, berangkat ke Bogor. Tidak hanya menghadiri acara SL II, dia juga mengikuti Sarasehan Nasional Taman Nasional. Lantaran itu, hampir tiga pekan, Burung meninggalkan rumah panjangnya. "Luar biasa," katanya, "capek tapi puas." Memang, setiap kepuasan hanya bisa diraih dengan pengorbanan. Banyak sekali pengetahuan baru yang diperoleh Burung; bahkan, pengetahuan di luar persoalan konservasi dan pengelolaan sumberdaya alam. Pengetahuan tidak hanya diperoleh dari dinamika masyarakat Gunung Simpang, Cianjur Selatan, Jawa Barat—salah satu tempat berlangsungnya SL II, dalam mengelola sumberdaya alam tetapi juga dari peserta lain yang berasal dari banyak tempat di Nusantara.

Sesampainya di Sungai Pelaik, Burung menceritakan pengalamannya kepada para kerabat dan warganya. Lantas, pengalaman pria murah senyum ini dirembuk bersama-sama. Kondisi lingkungan dan permasalahan yang dihadapi warga Sungai Pelaik berbeda dengan persoalan masyarakat Gunung Simpang. "Desa Neglasari," kata Burung seakan menunjukkan kenangan manisnya pada desa tempat SL II digelar. Persoalan yang membelit warga Sungai Pelaik adalah penegakan aturan-aturan adat, khususnya, peraturan menangkap ikan di wilayah tradisional mereka. Cukup banyak pelanggaran wilayah dilakukan orang-orang dari kampung tetangga, seperti memasang alat penangkap ikan yang dilarang, pukat.

Bulan Oktober 2005 silam, sebanyak 150 rol pukat ditemukan di Danau Telatap, masih wilayah Sungai Pelaik. Selain membuat ikan berubah liar, pukat-pukat ini, menurut pengetahuan orang Iban, menghabiskan ikan. Pemanenan dengan pukat itu telah terjadi sebanyak tiga kali sepanjang tahun 2005. Para pelanggar ini berasal dari Kampung Semalah, kampung orang Melayu. Burung berpikir, nampaknya, ini saat yang tepat memulai perubahan. Bekal dari SL II masih hangat. Diiringi sejumlah teman, timbul keberanian mengunjungi Kampung Semalah. Diskusi dan negosiasi berlangsung dengan para pemimpin Semalah; meski alot, tapi berjalan lancar ketika membahas soal sangsi pelanggaran. Tercapai juga kesepakatan di antara kedua belah pihak yang dituangkan dalam surat perjanjian tertulis.

Satu lagi perjanjian tertulis berhasil disepakati antara Sungai Pelaik dan Kampung Tempurau. Perjanjian ini berkaitan dengan pengelolaan Danau Bejele' soal pengaturan waktu pemanenan ikan untuk mencegah punahnya ikan. Meski tak luas, Danau Bejele,'juga wilayah adat Sungai Pelaik, menjadi tempat ikan beranak pinak sebelum akhirnya menyebar luas.

Toh, benak Burung masih tertambat di Desa Neglasari. Pengalamannya melihat kincir air tenaga listrik di desa itu menyulut keinginannya untuk membuat Sungai Pelaik benderang. Menurutnya, situasi dan kondisi Sungai Pelaik cocok dengan teknologi itu. Modal alam sudah mendukung, air sungai mengalir deras. Mustahil pula berharap aliran listrik PLN. Menggunakan generator diesel? Harga BBM di Sungai Pelaik: Rp. 8000 perliter. Burung tak sendirian, anggota masyarakat rumah panjang memiliki mimpi yang sama. Foto-foto kincir air di Cianjur, yang diabadikan Burung, berulang kali disimak dan dibicarakan. Sungai Telatap, selebar empat meter, disurvei bersama-sama sambil berangan-angan suatu saat kincir air berputar untuk tenaga listrik.

Kini, mimpi itu mendekati kenyataan. Dibantu warga Desa Neglasari, pelan-pelan, Burung mewujudkan keinginannya untuk menerangi Kampung Pelaik. Sebuah pertukaran pengetahuan, diam-diam, terjadi antara Danau Sentarum di pelosok Kalimantan Barat dengan Neglasari di pojok Cianjur Selatan, Jawa Barat. 


\section{Pembelajaran bagi Pengelolaan Sumberdaya Alam Indonesia}

Sehabis SL V, Kemitraan dalam Pengelolaan Sumberdaya Air, Yogyakarta, Desember 2006, sempat dilakukan diskusi antara fasilitator, penyelenggara dan beberapa peserta yang pernah mengikuti forum ini lebih dari satu kali. Diskusi itu dimaksudkan sebagai sedikit evaluasi dan refleksi pengalaman mereka selama mengikuti proses pembelajaran SL.

Yang menarik, diskusi justru diawali dengan pengertian SL itu sendiri. Tampaknya, meski dipahami berbeda-beda di antara para pembelajar, namun perbedaan pemahaman itu tidak berseberangan, tetapi malah saling melengkapi. Secara umum, SL dipahami sebagai:

Berbagi informasi, perubahan pengetahuan, berbagi pengetahuan dan pengalaman, belajar bersama, belajar berdasarkan pengalaman, refleksi atas pengalaman dan berbagi ketrampilan, belajar bersama melalui berbagai metode yang efektif, berbagi pengalaman dalam tindakan yang difasilitasi dan diorganisasi.

Definisi yang beragam ini menunjukkan penekanan yang berbeda atas hal-hal pokok antara SL, yang diselenggarakan CIFOR-PILI, dengan kegiatan serupa dari organisasi lain. KARSA (Lingkaran Pembaruan Desa dan Agraria), misalnya, menyelenggarakan kegiatan belajar bersama yang lebih mirip kursus/serial/tematik berupa paket kursus yang dilengkapi studi banding dengan satu kelompok peserta. Atau, MFP-DfID dengan shared learning-nya yang lebih berupa lokakarya wilayah untuk mempersatukan semua peserta dalam kegiatan MFP.

Ajang SL yang diselenggarakan CIFOR-PILI mempunyai dinamikanya sendiri. Kombinasi teknik fasilitasi, penekanan pada pengalaman dan adanya 'residivis', atau alumni SL sebelumnya, membuat proses belajar lebih hidup. Bentuknya lebih mirip 'cerita bersambung' dengan masing-masing episode yang berdiri sendiri. Substansi dan topik SL, serta hadirnya para alumni, merupakan perekat untuk mendorong proses belajar. Dengan demikian, pembahasan topik tidak terlalu mendalam karena diharapkan peserta melakukan pembelajaran dengan caranya sendiri: bagaimana mendapatkan informasi yang diperlukan, berkomunikasi sekaligus membentuk dan memelihara jaringan antarpeserta. 
Meskipun tanpa defisini baku, semua pihak terkait sepakat mengenai tujuan forum SL:

- Belajar hal baru - proses dari tidak tahu menjadi tahu: pengetahuan, keterampilan, sikap/perilaku, nilai,

- Mencari pendekatan yang terbaik,

- Alat untuk mempercepat tindakan kolektif untuk mendorong perubahan.

Sejauh pengalaman tujuh serial SL ditemukan pula tema-tema yang diusung dalam beberapa SL — seperti, kolaborasi dalam kawasan konservasi, pemanfaatan hasil hutan bukan kayu, pengelolaan sumberdaya air, monitoring dan evaluasi kolaboratif - adalah relevan dan bermanfaat bagi peserta untuk memahami pengelolaan sumberdaya alam secara lebih luas dan mendalam. Penting untuk diketahui, tema-tema tersebut ditentukan berdasarkan masukan dari peserta seri SL sebelumnya.

Selain itu, tampak semakin praktis suatu topik (seperti pengelolaan sumberdaya air dan pengelolaan hasil hutan bukan kayu) belum tentu menjamin lebih menarik ketimbang tema yang konseptual (seperti kolaborasi dalam kawasan konservasi, pengelolaan konflik atau tata ruang).

Namun, satu hal yang pasti, SL menyediakan tambahan pembelajaran bersama melalui kajian lapangan di lokasi tertentu, yang ternyata selalu memberi peluang adanya 'tema baru' yang dipelajari. Misalnya, ketika SL III di Tangkahan, yang menelaah Manajemen Konflik dalam Pengelolaan Sumberdaya Alam, pengamatan lapangan justru memberikan hikmah lain tentang pengelolaan ekowisata berbasis masyarakat.

Atau, di Tomohon (SL IV, Kemitraan dalam Pengelolaan Hasil Hutan bukan Kayu) yang malah membuka mata peserta tentang keunggulan pohon aren, baik secara ekologi maupun ekonomi. Pelajaran tambahan juga diperoleh melalui diskusi antarpeserta di luar acara resmi SL, ketika istirahat atau sesudah makan. Misalnya, pertukaran pengetahuan mengenai cara menanam kentang organik muncul dari pembicaraan antarpeserta di luar acara terstruktur.

Masih berkaitan dengan dampak belajar bersama, bisa dilihat beberapa individu mampu belajar banyak dari kegiatan SL dan mencoba untuk berbagi dengan masyarakat di kampungnya. Dengan demikian, harapan arena belajar bersama ini dapat mendorong pembelajaran sosial yang lebih luas cukup beralasan. Hanya saja, masih diperlukan usaha untuk menemu-kenali dampak yang lebih 
luas, melebihi dampak bagi individu. Kendati demikian, di setiap SL, peserta selalu memperlihatkan antusiasme dan keterikatan mereka dalam menyusun perencanaan SL ke depan.

Saat merefleksikan proses belajar, tim penggerak SL_fasilitator, pengamat dan penyelenggara - mendapati bahwa penggunaan metode fasilitasi yang bervariasi, kendati dimaksudkan untuk mengurangi kebosanan, tidak selamanya kondusif untuk memandu pembelajaran. Sejumlah pembelajar, bahkan, mengalami kesulitan untuk mengikuti metode-metode yang berbeda

Sangat penting untuk mendiskusikan lebih seksama mengenai pro dan kontra melibatkan peserta sebagai fasilitator, khususnya, dalam kajian desa. Untuk menentukannya sangat tergantung dari kapasitas pembelajar(tidak semua peserta memiliki ketrampilan fasilitasi), kondisi pembelajaran dan situasi lokal tempat kajian lapangan (perbedaan bahasa, misalnya). Dibutuhkan pertimbangan matang untuk menentukan kapan fasilitator membantu peserta dan kapan peserta dibebaskan untuk memfasilitasi dirinya secara mandiri.

Berjaringan menjadi satu hal yang secara eksplisit didorong untuk dikembangkan oleh para peserta. Sayangnya, kegiatan membangun jaringan ini masih belum berjalan lancar sepenuhnya. Meskipun telah disediakan fasilitas mailing-list, namun hingga saat ini belum dimanfaatkan secara maksimal. Selain itu, pernah diupayakan adanya publikasi sebagai media komunikasi, namun juga belum berjalan dengan baik.

Kendati demikian, belakangan, hubungan antarpeserta melalui telepon genggam (komunikasi melalui telepon dan surat menyurat singkat/SMS) justru jauh lebih meningkat dan berkembang. Alat komunikasi ini memang nyaris tersebar luas dan dimiliki oleh para peserta. (Lihat Kotak 3.). 


\section{Kotak 3. Menyemai Jaringan dari Genggaman Tangan.}

Meluasnya jaringan telepon genggam membuka kesempatan bagi tersebarnya jaringan antar-alumni SL. Meski tak selalu menyangkut hal-hal serius, setidaknya, SL telah menyulut niat para alumninya untuk berbagi informasi. Berikut ini beberapa rekaman komunikasi lewat surat menyurat singkat (SMS) sejumlah alumni SL.

Fitri, Sambak, Magelang, Jawa tengah, 08139247xxxx

Trims utk siang ini, tamu dr aceh bsr, para camat... Doakan kami bertahan dalam konservasi pnh intrik...

Mustakim, Bungo, Jambi, 0828748xxxx

Apakah sy diund... Sy sdang membuat alat u/ nanam jahe... Doakan berhsl...

Abah Anggun Hambawisesa, masyarakat Barukusumah, Kebunpeuteuy, Cianjur, 08191206xxxx

Ass. Sy mmbaca bk dr cifor yg diberikan kmrn... kpn ada acr sl lg... abah ingin ikut...

I Made Sugiarta, Bali, 0812469xxxx

Temans jgn lupa... saksikan metro tv, kegiatan kami masuk ekspedisi, jam $10 \mathrm{mlm}$ ini...

Ova, Nusa Tenggara Timur, 08180575xxxx

Trima ksh dah diundang... mudah2an sy bisa praktkan didaerah sy yg trpencil ndak ada listrik dan bs memberdyakan perempuan di sini

Elisar Ipuy, Setulang, Malinau, Kalimantan Timur, 0817842xxxx

Hutan setulang msh hijau... apa kbr... kami tetap berthan...

Kalo ada kbr ttg setulang tlong kami diberitahu dan kirimkan...

\section{Tantangan dan Saran}

Setiap pelaksanaan SL selalu memunculkan hal-hal baru yang bisa dipetik dan bermanfaat untuk terus memperbaiki pendekatan pembelajaran sosial ini. Sejauh pengalaman itu pula, dapat dicermati hal-hal yang dianggap oleh peserta sebagai penghambat dalam menjalani proses SL. Karenanya, hal tersebut menjadi tantangan dalam meraih kesuksesan penyelenggaraan SL. Berikut ini, sejumlah tantangan, dan saran-sarannya:

- Bahasa 'langit' dan bahasa 'bumi'. Inilah hal yang paling sering disampaikan oleh peserta pada setiap SL digelar; berkenaan dengan 
banyaknya penggunaan istilah asing dengan bahasa yang dianggap 'tinggi'-bahasa langit—dan asing bagi telinga peserta. Tak jarang, tanpa disadari, di antara peserta, narasumber, reviewer, dan fasilitator, begitu banyak memakai istilah-istilah baru. Beberapa hal yang dapat dilakukan: meng-indonesia-kan (bahasa bumi) istilah asing yang dipakai (seperti, partisipatif menjadi peran-serta, responsif menjadi tanggap), memberikan penjelasan lebih lanjut, atau membuat pojok informasi yang memuat istilah beserta penjelasan singkatnya yang ditempelkan selama kegiatan berlangsung. Di lain pihak, banyak kata yang dianggap sebagai 'bahasa langit' ternyata sudah banyak "merakyat" sehingga pada beberapa kegiatan SL terakhir, perhatian terhadap hal ini makin berkurang.

- Ketidaksetaraan peserta. Latar belakang peserta yang sangat beragam, tak jarang menjadi batu sandungan dalam proses belajar. Pembelajar masih terbiasa berperan dengan posisinya masing-masing. Karenanya, membangun kesetaraan menjadi hal yang penting dalam mendukung proses belajar bersama. Selama SL, biasanya, dilakukan penyadaran bahwa inti dari hubungan multipihak adalah hubungan antarmanusia, bukan antarposisi atau jabatan. Dengan demikian, harus ditegaskan bahwa semua peserta memiliki pengalaman yang pantas disampaikan dan patut dipelajari bersama. Selain itu, di sela-sela kegiatan SL diselenggarakan permainan-permainan yang berperan membangun kesadaran tim (team building).

- Dilema antara tema be2lajar dan pengalaman. Meskipun pengalaman merupakan bahan belajar utama, tetapi setiap seri SL mempunyai topik utama untuk mengarahkan pembelajaran. Lantas, topik utama diulas melalui pengalaman pembelajar. Hasil refleksi menunjukkan, bahan pelajaran yang ditawarkan cukup bervariasi dan sesuai dengan tema payung SL (kolaborasi), dan juga dipandang bermakna oleh peserta. Kekayaan pengalaman pembelajar harus diselaraskan dengan tema utama SL. Selain untuk menghindari melimpahnya informasi, topik utama menjadi panduan untuk mengarahkan perjalanan proses pembelajaran tanpa mengurangi kekayaan informasi dari peserta.

- Keterbukaan ada batasnya. Tanpa bermaksud mengurangi kesempatan partisipasi peserta, keterbukaan dalam pembelajaran bersama perlu dikelola. Keterbukaan diwajibkan, untuk memberi kesempatan bagi peserta membagi pengalaman dan pengetahuan. Dengan demikian, sejak masa persiapan SL, pembelajar harus dipilih yang memiliki pengalaman yang sesuai dengan tema pembelajaran dan bersedia untuk berbagi pengalaman dengan pihak lain. Keterbukaan berkaitan erat dengan kesejajaran setiap 
peserta. Tim penggerak SL harus mengelola keterbukaan dengan tetap menjamin tercapainya partisipasi penuh dari peserta, karena tak jarang terjadi sejumlah orang atau kelompok terlalu mendominasi forum.

- Variasi teknik dan metode. Peserta pada umumnya menyukai kegiatan berbagi pengalaman dan kunjungan lapangan. Akan tetapi untuk meningkatkan pengalaman sebagai sumber pelajaran, peserta (dan fasilitator) perlu dirangsang agar lebih reflektif. Tiap SL dirancang agar ada variasi berbagai metoda dan teknik pembelajaran. Hanya saja, variasi yang terlalu banyak belum tentu efektif. Di samping itu, tujuan yang tersirat dalam pemilihan metodologi tertentu juga kurang terangkat. Persiapan rancangan proses harus lebih cermat dengan penentuan metode yang tepat untuk keadaan tertentu. Penyelenggara dan fasilitator pun harus belajar serta bekerja secara lebih sadar, terarah, lebih reflektif dan lebih partisipatif.

- Format dan proses belajar yang baku. Meskipun belum ada format dan proses baku, pada SL V di Yogyakarta, sudah mulai ada struktur baku. Pertanyaannya, apakah perlu format dan proses baku? Apakah selalu diperlukan teknik baru untuk setiap SL? Satu hal yang muncul dari setiap kali refleksi: forum seminar di hari pertama sering berlangsung membosankan. Meniadakan seminar juga bukan persoalan gampang karena forum hari pertama ini juga bertujuan diplomatis dan menjelaskan kerangka proses pembelajaran seterusnya. Satu pilihan yang dapat dipertimbangkan, mengganti peran narasumber bukan sebagai pemberi materi seminar tetapi sebagai pembahas pengalaman peserta, atau sebagai 'dokter' saat sesi klinik yang membahas topik pilihan peserta. Juga ada kecenderungan dan ketergantungan pemaparan presentasi dengan perangkat komputer (aplikasi powerpoint) dan sambungan listrik. Padahal, tidak semua tempat dijumpai aliran listrik atau generator. Kemampuan penyampaian tanpa aplikasi powerpoint perlu dipelihara.

- Narasumber lokasi kajian lapangan. Kajian lapangan merupakan arena belajar yang disukai, baik oleh peserta SL maupun masyarakat setempat. Untuk masyarakat setempat, kajian desa membuat mereka melihat desanya/kehidupannya dengan 'kacamata' yang berbeda. Kendala utama selama ini, kurang tersedianya narasumber lokal. Untuk mengatasi hal ini, bisa diterapkan metode tungku: pembelajar memanfaatkan waktu di rumah pondokan, bersama tuan rumahnya untuk berbagi pengalaman. Dan, diberi peluang untuk melaporkan kembali pada kelompoknya. Hasil kajian lapangan juga perlu ditindaklanjuti oleh pemerintah setempat agar 
bisa menggulirkan perubahan di lokasi belajar. Untuk itu, juga harus ada kehadiran peserta dari lokasi kajian lapangan yang mengikuti SL sejak awal hingga akhir.

- Meretas jalan bagi pembelajaran bersama. SL telah memberi sebuah teladan tentang perlunya forum belajar bersama bagi para pesertanya. Sejauh pelaksanaan SL, terlihat sejumlah pembelajar memiliki semangat untuk melanjutkan forum belajar bersama sementara peserta yang lain masih nampak setengah hati. Sangat disadari dengan baik, setidaknya, untuk menyulut pemahaman kritis dalam merumuskan pertanyaan yang bernas. Dampak belajar bersama seringkali baru terlihat dalam jangka waktu tertentu pasca-SL. Sejak awal, sudah diikhtiarkan untuk melihat perkembangan belajar bersama para peserta di daerah asalnya. Sayangnya, hal itu hanya dilakukan ketika ada kesempatan, secara kebetulan, bertemu alumni SL. Hakikat SL, sejatinya, terletak pada proses belajar bersama, bukan pada bentuk atau wadahnya. Banyak dijumpai, di luar acara resmi SL, pembelajaran berkembang di luar tema pokok. Misalnya, tentang pembentukan Badan Perwakilan Desa (BPD); peserta yang berpengalaman mengembangkan proses pembentukan BPD secara partisipatif, terbuka dan bertanggung jawab, bisa menularkannya kepada yang lain.

- Proses belajar harus berwatak adaptif. Dari hasil pengamatan tim penggerak SL, terlihat proses pembelajaran agak tidak pasti dan dipengaruhi oleh banyak hal. Secara internal, proses belajar dipengaruhi oleh kemampuan peserta dan fasilitator-ketrampilan, pengalaman dan pengetahuan. Begitu juga faktor eksternal, seperti suasana ruangan, cuaca, ketersediaan listrik dan sebagainya, juga turut mempengaruhi proses belajar. Dengan demikian, proses belajar sedikit-banyak harus adaptif. Sejatinya pula, tema umum kegiatan SL bersifat adaptif, lentur dan kreatif.

- Rencana Tindak Lanjut (RTL). Tahap ini cukup penting untuk mendorong keberlanjutan SL ini. Akan tetapi, selama ini, RTL jarang cukup realistis dan tidak pernah dipantau. Sebaiknya, diluangkan waktu untuk menyusun RTL yang realistis, terjangkau dan praktis. Agar RTL lebih bermakna, dan bisa memberi gambaran tentang kelanjutan proses belajar di daerah asal peserta, perlu juga disusun rencana pemantauan.

- Jaringan. Kekuatan utama SL adalah terbentuknya jaringan antarpeserta. Diharapkan, jaringan yang terbentuk akan menjadi ajang belajar bersama jarak jauh. Dari sini, selanjutnya, bisa digunakan sebagai sarana mencari informasi, pengetahuan baru, mencari bantuan atau jawaban atas pertanyaan yang ada tentang banyak hal. 


\section{Melanggengkan Pembelajaran Bersama}

Forum SL yang digelar melintasi beragam tema dan menjelajahi banyak daerah lokasi pembelajaran. Sepanjang itu pula, proses pembelajaran bersama telah dilalui. Seluruh catatan dalam pustaka ini diharapkan mampu menampung kekayaan pengalaman dan pengetahuan selama menggelar SL sebagai salah satu pendekatan pembelajaran sosial.

Sekali lagi, inti forum SL tersirat dan terpendam dalam proses belajarnya, bukan pada bentuknya. Sebagai sebuah panduan, pustaka ini memang baru menyentuh permukaan dari sebuah forum belajar bersama. Bekal pengalaman dari serentetan seri-seri SL mengajarkan, pengetahuan menemukan kemanjurannya ketika dilakukan secara nyata—dengan menggelar forum belajar bersama.

Berderet-deret tulisan dalam buku ini dimaksudkan untuk berbagi hikmah dalam menyelenggarakan forum SL. Menyadari begitu beragamnya topik, pemangku kepentingan, sosial-budaya, dan keadaan alam, buku ini tidak dimaksudkan untuk membatasi media belajar bersama yang akan dan sedang dikembangkan oleh siapapun. Justru penerapan buku panduan ini secara kaku yang harus dihindari. Dengan demikian, didasari keyakinan tentang watak belajar bersama yang adaptif, lentur dan kreatif, seluruh catatan dalam buku ini masih bisa ditambah, dikurangi maupun dikembangkan.

Untuk meladeni hakikat belajar bersama dalam SL: pustaka ini tak pernah rampung. Siapa pun yang mengembangkan dan menyebarkan pembelajaran bersama, ketika membaca buku ini, ikut menambah perbendaharaan pengalaman yang tertulis dalam buku ini. 


\section{Bahan Bacaan}

Braakman, L. 2002. Seni Membangun Kapasitas Pelatihan dalam Pengembangan Komuniti Forestri. Penerjemah: Budhita Kismadi dan Andri Novi. RECOFTC.

Cooperrider, D. dan S. Srivasta. 1987. Appreciative Inquiry into Organizational Life. Organizational Change and Development, Vol. 1.

Evans, K., S. J. Velarde, R. P. Prieto, S. N. Rao, S. Sertzen, K. Davila, P. Cronkleton dan W de Jong. 2006. Field Guide to the future: Four Ways for communities to think ahead. CIFOR, ICRAF, ASB.

Fahmi, E. dan Y. R. Zakaria. 2005. Good Governance dan Multi-stakeholder Processes: Minus Malum dalam Wacana NeoLiberalisme. Dalam: WACANA No. XX/2005, INSIST, Jogjakarta.

Kompas. 2007. Penghancuran Lingkungan Berlanjut. Edisi 6 Januari 2007.

Kusumanto, T., L. Yuliani, P. Macoun, Y. Indriatmoko, dan H. Adnan. 2006. Belajar Beradaptasi: Bersama-sama Mengelola Hutan di Indonesia. CIFOR, Bogor, Indonesia.

Laird, D. 1985. Approaches to Training and Development. Addison-Wesley Publishing Company, Massachusetts.

Meier, D. 2003. The Accelerated Learning Handbook: Panduan kreatif dan efektif dalam merancang program pendidikan dan pelatihan. Pustaka Kaifa, Bandung.

Pretty, J. N., I. Guijt, J. Thompson, dan I. Scoones. 1995. Participatory Learning \& Action: A Trainers's Guide. IIED Participatory Methodology Series. 
74 Belajar sambil Mengajar: Menghadapi Perubahan Sosial untuk Pengelolaan Sumberdaya Alam

Seidmen, E. 1983. Handbook of Social Intervention. Sage Publication, Beverly Hill.

Smith, W. A. 2001. Conscientizacao, Tujuan Pendidikan Paulo Freire. Penerjemah: Agung Prihantoro. Pustaka Pelajar, Yogyakarta.

Whitney, D., dan A. T. Bloom. 2007. The Power of Appreciative Inquiry: A Practical Guide to Positive Change. Edisi Bahasa Indonesia. B-First, Jakarta.

Wollenberg, E., D. Edmunds, L. Buck, dan S, Brodt. 2005. Pembelajaran Sosial dalam Pengelolaan Hutan Komunitas. CIFOR dan Pustaka Latin, Bogor, Indonesia.

Wollenberg, E., D. Edmunds dan L. Buck. 2000. Anticipating Changes: Scenarios as a tool for adaptive forest management. CIFOR, Bogor, Indonesia.

Zaltman, G., P. Kotler, dan I. Kaufman. 1972. Creating Social Change. Holt, Rinehart, and Winston Inc., New York. 
Center for International Forestry Research (CIFOR) adalah lembaga penelitian kehutanan internasional terdepan,yang didirikan pada tahun 1993 sebagai tanggapan atas keprihatinan dunia akan konsekuensi sosial, lingkungan dan ekonomi yang disebabkan oleh kerusakan dan kehilangan hutan. Penelitian CIFOR ditujukan untuk menghasilkan kebijakan dan teknologi untuk pemanfaatan dan pengelolaan hutan yang berkelanjutan, dan untuk meningkatkan kesejahteraan masyarakat di negara-negara berkembang yang bergantung kepada hutan tropis untuk kehidupannya. CIFOR adalah salah satu di antara 15 pusat di bawah Consultative Group on International Agricultural Research (CGIAR). Berpusat di Bogor, Indonesia, CIFOR mempunyai kantor regional di Brazil, Bolivia, Burkina Faso, Cameroon, Ethiopia, India, Zambia dan Zimbabwe dan bekerja di lebih dari 30 negara di seluruh dunia. 


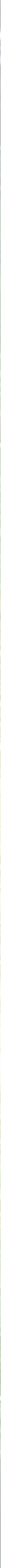

